\title{
Contribuição ao Conhecimento da Incidência de Leptospiras em Murídeos, Caninos e Suínos no Paraná
}

\author{
Marcos Augusto Enrietti \\ Instituto de Biologia e Pesquisas Tecnológicas
}

\begin{abstract}
This research carried out in the city of Curitiba took us to the following conclusions:

1) In the main zone of Curitiba city the leptospirosis index among the rats captured reached 78 percent. This index represent the greatest incidence verified till the present moment in Brazil.

2) The 'Rattus norwegicus' was the chief species among those rats (96 percent).

3) According to the results presented, the culturing methods are preferable to the inoculating one.

4) The combination of these two simple methods is more advantageous in the leptospira research.
\end{abstract}

Key words: Leptospirosis; Weil disease; Rattus norwegicus

\section{INTRODUÇÃO}

Em meados de 1946, ocorreu na zona agrícola da Colônia Federal "Marquês de Abrantes", Município de Bocaiúva do Sul (ex-Imbuial), uma invasão de ratos silvestres, ocorrência conhecida pelo nome de "ratadas", seguida de um surto epidêmico da Doença de Weil.

Os trabalhos de MIYAJIMA (1915), confirmados por numerosos autores, concluindo que os ratos domésticos e de campo são os reservatórios naturais da Leptospira icterohaemorrhagiae (INADA e IDO, 1915), levaram-nos, revendo a bibliografia e não deparando com qualquer estudo feito neste sentido no Estado do Paraná, a idéia de iniciarmos um trabalho que pudesse servir de ponto de partida à uma série de estudos complementares que o assunto comporta.
Objetivamos, nesta contribuição, determinar o índice de infestação nos ratos domésticos, estendendo as nossas pesquisas a cães de Curitiba e suínos abatidos no Matadouro Municipal e no Laboratório "Prado"1 desta Capital.

Infelizmente, por fatores alheios à nossa vontade, este trabalho não pode ser feito na ocasião das "ratadas", ocorridas em 1946 no nosso Estado, na qual poderíamos estabelecer a incidência de leptospira nos roedores silvestres, fato este que fica por determinar em nosso País.

Ao visarmos salientar esta incidência, tivemos em mente evitar os futuros perigos de "ratadas", acompanhadas de surtos epidêmicos da Doença de Weil, que, certamente, poderão coincidir com vindouras frutificações dos taquarais.

Tendo-se em vista que, por ocasião das aludidas "ratadas", é grande a existência de roedores em

\footnotetext{
$\wp$ Artigo publicado no Arquivos de Biologia e Tecnologia, v. 9, pp. 21-72, 1954.

1 - Tese de concurso à Cátedra de Doenças Infecto-Contagiosas e Parasitárias dos Animais Domésticos. Política Sanitária e Clínica, apresentada à Escola Superior de Agricultura e Veterinária do Paraná, em 1949.

- Aos Diretores do Laboratório "Prado" expressamos os nossos agradecimentos.
} 
zonas notadamente agrícolas, é bem de ver, que o homem do campo, estará, indiscutivelmente, mais do que qualquer outro, sujeito à infecção pela L. icterohaemorrhagiae.

Assim sendo, o interesse pelo assunto em apreço, fruto de nossa formação e orientação profissional, leva-nos a estudar os meios de melhorar e elevar as condições de vida do nosso homem rural.

A esse modesto obreiro da grandeza econômica do Paraná, dedicamos este trabalho.

Esta é apenas o início de uma série de outras pesquisas, pois pretendemos desenvolver um estudo completo, abrangendo várias zonas rurais do Estado, em virtude do alto interesse que apresenta o assunto e das condições especiais de transmissão do agente patógeno.

Dividimos este trabalho em duas partes: na primeira, estudamos a parte geral do assunto e, na segunda, explanamos a parte experimental realizada e os trabalhos executados.

\section{GENERALIDADES}

\section{A LEPTOSPIROSE DO HOMEM E DOS ANIMAIS}

Sob a denominação de Leptospirose designa-se um grupo de doenças causadas no homem e nos animais, por alguns representantes da ordem Spirochaetales, família Treponemataceae, gênero Leptospira, que abriga numerosas espécies, das quais, por serem mais difundidas no nosso meio, interessam-nos as seguintes: Leptospira icterohaemorrhagiae (INADA e IDO, 1915) e Leptospira canicola (SCHÜFFNER, 1934), agentes etiológicos das doenças de Weil e Stuttgart.

Esta infecção é conhecida desde HIPÓCRATES, quem primeiro descreveu a icterícia infecciosa, que foi determinada e diferenciada de outras infecções por CLEFTON citado por BACHMANN (1944), em Minorca, e LARREY (1800), médico militar francês, que observou no exército napoleônico, no Egito, dois casos de icterícia infecciosa, no Cairo, e por WEIL (1886), que descreveu uma doença caracterizada por icterícia, esplenomegalia e nefrite, no que foi secundado por FIEDLER (1892), que lhe emprestou as características de uma doença infecciosa autônoma.

O estudo da Leptospirose icterohemorrágica, teve um grande desenvolvimento, durante a guerra de 1914/18, quando se sucederam vários surtos da moléstia entre as tropas que se encontravam nas frentes de batalha. Durante esse período, foram registrados 350 casos de doença, na França.

As primeiras vítimas se encontravam entre os soldados da frente italiana, passando a seguir, para as frentes inglesa, alemã e francesa, onde ocorreram formas epidêmicas da moléstia.

A investigação foi confiada a PETTIT e MARTIN (1919), coletando o primeiro, farto material, que, enviado ao Instituto Pasteur, para os devidos estudos, tornou possível estabelecer as principais características da doença e oferecer amplo conhecimento a seu respeito.

A determinação da especificidade do agente patogênico deve-se a dois médicos japoneses, INADA e IDO (1915), que, em novembro de 1914, consignaram sua presença no fígado de um cobáio, inoculado com o sangue de um doente atacado de icterícia infecciosa, denominando-o de Spirochaeta icterohaemorrhagiae, e para o qual, mais tarde, NOGUCHI (1917), propôs a criação do gênero Leptospira, passando a denominar-se Leptospira icterohaemorrhagiae.

Mais ou menos nessa época, na Alemanha, HUEBENER e REITER (1915), de um lado, e UHLENHUTH e FROMME (1915) de outro, disputaram o mérito desta constatação, pois ignoravam os trabalhos dos japoneses, devido as dificuldades de comunicações durante a guerra mundial.

No entretanto, o primeiro microorganismo do gênero Leptospira foi isolado por WOLBACH e BINGER (1914), em água de poço. A espécie isolada, com a denominação de Spirochaeta elusa, atualmente conhecida como Leptospira biflexa, não era patogênica para ratos brancos, cobáios, coelhos e rãs. Subseqüentemente, foram isoladas das águas estagnadas, espécies de leptospira, patogênicas para ratos e cobáios e, presumivelmente, para o homem.

ZUELZER (1921), foi quem primeiramente verificou tais fatos, no que foi seguido pelas afirmações de BUCHANAN (1924) e outros. IDO, ITO e WANI (1918), isolaram um germe que apresentava certa similitude com o microorganismo da Doença de Weil. Este microorganismo que determina um processo febril cuja duração é de 7 dias, foi denominado pelos autores de Spirochaeta hebdomadis, encontrandose, atualmente, classificado no gênero Leptospira. No Japão, a enfermidade produzida por esta 
Leptospira, é conhecida pelo nome de Nanukayami.

Nesse mesmo ano, outros investigadores japoneses descreveram uma leptospira denominada $L$. autumnalis que provoca um estado febril benigno, aparecendo no Japão, epidemicamente, nos meses de outono, cuja enfermidade é designada pelo nome de Akiyami.

No espaço de tempo decorrido entre 1916 e 1928, NOGUCHI, estudando em seu laboratório em New York, material originário de uma epidemia de Leptospirose que ocorrera em Guayaquil, no Equador, em virtude de um equívoco que se tornou célebre pela confusão feita no diagnóstico por clínicos locais, isolou uma leptospira a qual denominou L. icteroide, considerando-a como o agente da Febre Amarela. Entretanto, posteriormente, foi reconhecida, através de trbalhos imunológicos, como sendo idêntica à Leptospira icterohaemorrhagiae (INADA e IDO, 1915).

Além das espécies já descritas, outras existem como L. bataviae, grippo-typhosa, pomona, sejrö, andaman, bonariensis, javanica, australis, salinem, pirogenes, etc., classificadas como espécies diferentes em face de estudos imunológicos, com o auxílio de soros aglutinantes. MIYAJIMA (1915), chamou a atenção para a presença de espiroquetas nos rins dos ratos de campo (Microtus montebelloi).

A inter-relação entre a doença e os roedores, foi confirmada por IDO et al. (1916), que encontraram os microorganismos nos rins de ratos domésticos.

Até pouco tempo, os animais domésticos eram considerados refratários à leptospira patogênica para o homem, natural ou experimentalmente. Porém, diversas pesquisas mostraram que nem sempre é assim, pois que, além do cão, outros animais podem contrair a infecção, seja por contaminação natural ou experimental.

MELANIDI, TZORTZAKI e DEBONERA (1933) inocularam um leitão com amostras provindas da Grécia, pela via intratesticular. O leitão teve um acesso febril e o seu sangue inoculado em cobáio, não transmitiu a doença e não o imunizou.

SANDEK (1935), fez uma observação que parece mostrar a suscetibilidade do suíno. Um suíno ictérico foi abatido por um indivíduo que apresentou icterícia 8 dias após o sacrifício do mesmo. $\mathrm{O}$ soro do doente aglutinava fortemente a L. icterohaemorrhagiae e desviava o complemento em presença desta leptospira.
SANDEK observou, ainda, a freqüência da enfermidade em empregados de matadouros, porém, a origem da infecção suína não foi possível ser demonstrada satisfatoriamente, pois o soro desses animais não aglutinou a leptospira.

KLARENBEECK e WINSSER (1937), isolaram a L. icterohaemorrhagiae em 4 leitões que apresentavam icterícia aguda. A cultura do agente infeccioso e a subsequiente inoculação em cobáio provocaram a doença. Nos leitões curados, a urina continha o microorganismo e o sangue apresentava uma ação lítica sobre a $L$. icterohaemorrhagiae e nula sobre a $L$. canicola.

MOCHTAR (1940), examinando os rins de 104 suínos, nos arredores de Batávia, isolou, por meio de cultura, 6 amostras de leptospira pouco virulentas para o cobáio e rato branco. Estudando, sorologicamente, estas amostras, verificou que correspondiam à L. pomona dos investigadores australianos.

JOHNSON (1943), encontrou nos suínos de South Queensland (Austrália), L. pomona e L. mitis ou bataviae.

NIESCHULZ e WAWO-ROENTOE (1930), inocularam cultura de $L$. icterohaemorrhagiae num eqüino, o qual apresentou infecção típica com presença de lisinas e aglutininas. $\mathrm{O}$ sangue injetado em outro animal $(150 \mathrm{ml})$ determinou a morte pela infecção no fim de 7 a 8 dias, com icterícia típica. Necropsiado, encontrou-se leptospira nos órgãos.

Em ovinos a doença natural nunca foi observada. MELANIDI, TZORTZAKI e DEBONERA (1933), afirmaram ter observado em 1921, na Grécia, uma enzootia ictérica grave com marcha contagiosa. Os autores gregos inocularam cordeiros por via intratesticular e observaram que os animais apresentavam elevação térmica, verificando a presença de leptospira pela infecção experimental no cobáio. A soro-aglutinação foi positiva. As inoculações intraperitonial e intracerebral não deram resultados. Em cabras, os autores obtiveram os mesmos resultados.

A Doença de Weil encontra-se difundida em todo o globo e descrita na maioria dos países, segundo a distribuição dos portadores naturais do agente etiológico. Os países mais atingidos são aqueles onde predominam as zonas mineiras, tais como: Inglaterra, Bélgica e Japão.

Uma das causas que concorre para o elevado índice da infecção na Inglaterra e no Japão, é o costume que têm os mineiros e agricultores de trabalharem descalços nas minas e nas plantações 
de arroz, expondo-se assim, ao contato das leptospiras que se encontram nos alagadiços e no lodo do fundo das minas, razão pela qual a Doença de Weil nestas regiões é conhecida pelos nomes de: Febre da Lama, Febre das Inundações e Febre dos Campos.

SCHÜFFNER e WALCH-SORGDRAGER (1938), consideraram a Febre dos Pântanos como uma doença à parte, determinada por uma outra espécie de leptospira, em virtude da localização intestinal muito semelhante à influenza e a febre dos 7 dias, conhecidas pela denominação de Nanukayami. Admitem estes autores existir na Europa três espécies patogênicas: $L$. icterohaemorrhagiae, L. canicola e Leptospira da Febre dos Pântanos ou "slime fever" dos ingleses.

A infecção pode produzir-se por ingestão de água ou de alimentos contaminados com urinas de ratos ou de cães com leptospirúria ou, por penetração do agente etiológico contido em águas contaminadas, através de erosões da pele como ocorre com operários que trabalham nas fossas. Nos banhos acidentais em águas contaminadas, a leptospira penetra através às mucosas nasal, bucal ou rinofaringeana. A via buco-nasal desempenha sem dúvida, papel saliente na aquisição da doença, porquanto, a ingestão de águas poluídas ou mesmo a fragilidade das mucosas naso-buco-faringeanas são capazes de permitir a entrada do agente infeccioso.

Excepcionalmente, a doença é transmitida pela mordida de ratos infectados.

Segundo os estudos de WALCH-SORGDRAGER (1939), em 91 por cento dos casos, a leptospira é transmitida pelo contacto com águas contaminadas pelas urinas de ratos e cães com leptospirúria e, os restantes 9 por cento pelo contacto direto.

$\mathrm{Na}$ Holanda, predomina a $L$. canicola isolada e descrita por SCHÜFFNER (1934), a qual tem por reservatório natural o cão.

A virulência e o índice de mortalidade da doença, varia de acordo com os fatores ecológicos. Decorre esta afirmação do fato de que, em certos países, a mortalidade varia em largas proporções. $\mathrm{Na}$ Europa a mortalidade era aproximadamente de 5 a 10 por cento, sendo que na Bélgica, excepcionalmente, a mortalidade atingiu numa epidemia a alta cifra de 23 por cento, enquanto que no Japão, o índice normal atinge 40 por cento.

No Brasil, foi a Leptospirose descrita pela primeira vez por BEAUREPAIRE DE ARAGÃO (1917), o qual demonstrou a presença do microorganismo em ratos, chamando assim, a atenção, para a existência da infecção em nosso País.

Em São Paulo, CARINI (1918), foi quem, pela primeira vez, examinando ratos procedentes do bairro Ponte Grande, demonstrou a existência da L. icterohaemorrhagiae em ratos, naturalmente infectados.

SMILLIE (1921), em São Paulo, foi o primeiro a realizar estudos sistemáticos, examinando 41 ratos capturados em várias zonas da cidade, e após inocular a emulsão renal desses ratos em cobáios, obteve 4 casos positivos, o que equivale a menos de 10 por cento.

FONSECA e PRADO (1932), em 31 ratos, obtiveram 13,8 por cento de casos positivos, ao examinarem em campo escuro, macerado de rins.

SAVINO e RENNELLA (1945), do Instituto Bacteriológico "Carlos G. Malbrán", de Buenos Aires, em colaboração com FURLANETTO, do Instituto Butantã, verificaram que os ratos cinzentos de São Paulo, estariam, naturalmente infectados pela $L$. bonariensis, descrita pelos mesmos autores.

Após os trabalhos iniciados no Brasil por ARAGÃO e CARINI, e incrementada que foi a pesquisa pela íntima relação do quadro clínico entre a Leptospirose e a Febre Amarela, inúmeros autores nacionais pesquisaram e descreveram a presença dos portadores dos microorganismos em todos os recantos do Brasil.

VIANNA JUNIOR e GODOFREDO VIANNA (1926), sob a orientação de NOGUCHI, isolaram na Bahia, a L. icteroide, posteriormente identificada por ROCHA LIMA, como o agente da Doença de Weil, L. icterohaemorrhagiae.

MAC DOWELL (1925), relatou à Academia Nacional de Medicina, duas de suas observações, sobre a referida doença, tendo esse autor comprovado por exames de laboratório, a presença da leptospira de INADA e IDO, na urina de seus pacientes.

Nos Estados do Norte do País, foi positivada a existência da doença, pelos trabalhos de SELLARDS e de EDUARDO DE ARAUJO (1928), primeiro na Paraíba e o segundo na Bahia, os quais observaram a presença do microorganismo nos rins de ratos capturados nesses Estados.

ABDON LINS (1928), no Rio de Janeiro, publicou os resultados de suas observações em Rattus norwegicus, Mus musculus e Mus rattus, verificando a incidência de 16,4 por cento de casos positivos. 
AMADEU FIALHO (1936), em posterior verificação feita no Rio de Janeiro, em 34 exemplares de $R$. norwegicus, elevou o índice de infecção para 28,2 por cento.

No Sul do País, SEFTON (1938), demonstrou a presença da enfermidade em Porto Alegre, num paciente com icterícia discreta e, que falecera posteriormente, verificando a presença do agente etiológico na urina, no sangue e no suco gástrico.

Em 1941, nessa mesma cidade, COSTA, FAILLACE, VIEIRA DA CUNHA, NEVES, CLAUSEL, CHAVES e MEDINA (1942), descreveram pela primeira vez, no País, uma forma epidêmica da Doença de Weil. Esta epidemia ocorreu por ocasião da enchente do rio Guaíba, quando 40.000 flagelados se viram na contingência de se abastecerem das águas do rio que foram contaminadas em consequiência da grande mortandade de ratos, mortandade esta que se deu em virtude da elevação do nível das águas.

A doença começou a aparecer depois das águas terem atingido o nível máximo. Como era de se esperar, de início, o quadro clínico foi confundido com o de outras enfermidades, dadas às condições do momento, obrigado a um diagnóstico diferencial entre febre amarela, febre tifóide e doença de Weil.

$\mathrm{O}$ agente etiológico foi isolado de modo definitivo, após minuciosos e exaustivos trabalhos, e a doença foi reproduzida experimentalmente, em cobáios, por inoculações do sangue de um dos pacientes que apresentava quadro clínico característico da moléstia.

Em setembro de 1946, surge no Estado do Paraná, o segundo surto epidêmico da Doença de Weil, descrito no Brasil, tendo por local a Colônia Federal Agrícola "Marquês de Abrantes", Município de Bocaiúva do Sul (ex-Imbuial). Seu estudo foi feito por NORONHA DE MIRANDA (1946), com o auxílio laboratorial de XAVIER VIANA, os quais isolaram o agente infeccioso, confirmando tratar-se da Doença de Weil.

A incidência da enfermidade coincidiu com a invasão de ratos naquela região, muitos dos quais morreram pelo caminho e outros foram encontrados mortos em águas paradas. Periodicamente, certas zonas agrícolas do Paraná são assoladas por invasão de ratos silvestres, localmente designada pelo nome de "ratadas".

Observações feitas, indicaram coincidir essas invasões com a frutificação dos taquarais, cujo fruto é muito apreciado pelos ratos o que determinaria a aglomeração destes roedores, e, conseqüentemente, sua rápida multiplicação, facilitada, ainda, em virtude das raízes dos taquarais se prestarem à formação de ninhos. Uma vez escasseando os frutos, os ratos dirigem-se em bandos à cata de alimentos, procurando roças, paióis, etc., passando a destruir todas as plantações encontradas pelo caminho.

A mortalidade é grande e o perigo que representa para a disseminação de várias doenças é incontestável, mormente, para a Doença de Weil, pois os trabalhos de MIYAJIMA (1915), confirmados por IDO et al. (1916), comprovaram ser o rato o reservatório natural da $L$. icterohaemorrhagiae.

Não resta dúvida, de que a epidemia verificada em Bocaiúva do Sul (ex-Imbuial), coincidiu com a "ratada", estudada na mesma ocasião por GIOVANNONI, VELLOZO e KUBIAK (1946).

No entretanto, a verificação de que os ratos silvestres que habitam a região (Holochilus leucogaster, Oryzomys oliurus, Hesperomys tener, Akodon nigrita, Oryzomys sp., etc), sejam ou não portadores da leptospira, está sendo feita por nós.

O fenômeno das "ratadas", em relação ao ciclo vegetativo das taquaras, ainda não está bem esclarecido, porém, sua periodicidade segundo as observações feitas entre nós por PEREIRA (1940), GIOVANNONI et al. (1946), parece ser procedente. Além disso, devemos salientar que este fenômeno não é generalizado, pois, não são todas as espécies de taquaras cuja frutificação atrai os ratos silvestres, assim como há zonas em que este fenômeno é absolutamente desconhecido.

A doença no cão, Tifo Canino, Gastro-enterite Hemorrágica, foi descrita pela primeira vez por HOFER em 1850, despertando o interesse geral, quando observada como enzootia infecciosa, na Alemanha, em 1898, passando a ser conhecida como Enzootia Canina de Stuttgart - Doença de

\section{Stuttgart.}

A etiologia da Doença de Stuttgart foi durante muito tempo obscura. Alguns autores admitiam a hipótese de intoxicação, bem que às vezes, ficavam confusos pelo caráter enzoótico que tomava a enfermidade.

Outros autores, partidários da origem infecciosa, incriminavam agentes múltiplos: HUTYRA, uma bactéria do gênero Proteus; HORNING, colibacilos; ZSCOKKE, cocobacilos; LECLAICHE, PIRL e SCHEIBEL, bactérias bipolares e LUKES, cultivou cocos admitindo, porém, a infecção secundária. 
LUCET (1910), parece ter sido o primeiro a assinalar a presença de espiroquetas em coágulos sanguíneos, no tubo digestivo, de cães enfermos.

Em seguida, FAIRISE e THIRY (1913), durante um surto em cães de caça, recolheram material de ulcerações bucais e obtiveram uma cultura quase pura de bacilos e espiroquetas.

KRUMBEIN e FRIELING (1916), na Alemanha, baseados em observações epidemiológicas, admitiram a possibilidade do cão ser o portador de leptospira patógena, para o homem. Citaram dois casos de infecção humana por contacto com cão ictérico.

UHLENHUTH e FROMME (1918), estudando igualmente, cães ictéricos, na Alemanha, constataram a existência de espiroquetas no fígado destes animais e, demonstraram serem os espiroquetas os causadores da icterícia infecciosa.

LUKES e DERBECK (1923), descreveram em Brunn (Moravia), uma enfermidade de cães, caracterizada por gastro-enterite hemorrágica. Em alguns cortes de 9 rins de animais, encontraram um microrganismo que denominaram Spirochaeta melanogenes canis.

LUKES (1924), reproduziu a doença em cobáios, isolando espiroquetas dos rins de cobáios mortos, após 30 dias de sua inoculação.

KRIVACEK (1924), afirmou ter encontrado espiroquetas em 17 de 21 cães doentes de Tifo Canino, empregando o método de LEVADITI, em cortes de rins.

PANISSET e VERGES (1925), examinando 3 cães doentes de Gastro-enterite Hemorrágica, verificaram a existência de espiroquetas no rim de um deles.

HIESINGER (1925), em Viena, isolou espiroquetas em 25 cães com a Doença de Stuttgart.

OKELL, DALLING e PUGH (1925), na Inglaterra, estudando casos de espiroquetose, isolaram de uma forma ictérica um microorganismo muito móvel, que determinou por inoculação de material fresco, icterícia leptospirilar no cão e no cobáio. Verificaram os autores ser este espiroqueta muito semelhante à $L$. icterohaemorrhagiae.

KLARENBEECK (1928), na Holanda, assinalou a presença de espiroquetas em lesões renais crônicas, denominando-as Spirochaeta icterouremiae canis.

SABLAYROLLES (1928), não encontrou leptospira em rins de cães doentes de Tifo, e acreditou tratar-se da ocorrência de intoxicações classificadas como tifo. Em 50 cães sadios, encontrou espiroquetas no tubo digestivo e, admitiu que estes espiroquetas na gastro-enterite emigram para os outros órgãos, em particular o rim.

KORTHOF (1930), na Holanda, examinou cães doentes e sãos, entre 120 animais, 44 (36 por cento), apresentavam aglutininas no sangue para leptospira e as culturas foram negativas para todos os casos. Este trabalho apresenta interesse para o estudo da verificação de aglutininas no sangue circulante do cão.

KOUVENAAR e WOLFF (1930), em Medam (Sumatra), estudando a L. canicola em 106 animais, verificaram ser negativos os exames de urina e culturas de material de fígado. A cultura de material de rim foi positiva em 6 casos $(5,8$ por cento).

Examinadas estas amostras por ESSEVELD, COLLIER e MOCHTAR (1940), foram classificadas como L. hebdomadis.

AELLIG (1931), relatou em Berna, um surto epizoótico de Leptospirose Canina, com 90 por cento de mortalidade.

SCHÜFFNER (1934), estudando diversas amostras de leptospiras isoladas de cães na Holanda, descreveu uma nova espécie que denominou de L. canicola. Este autor chamou a atenção para a pouca virulência desta leptospira em relação ao cobáio e, verificou que os cães restabelecidos eliminavam leptospira pelas vias urinárias.

REITANO e MORSELLI (1935), em Roma, verificaram em 112 cães examinados, soroaglutinação positiva para 4 (3,5 por cento).

UHLENHUTH e ZIMMERMANN (1936), examinando o sangue de 90 cães procedentes de 4 cidades alemãs, verificaram resultados positivos para soro-aglutinação, variando de 12 a 20 por cento.

HUGUENIN e BOURGEOIS (1936), confirmaram a evolução da doença experimentalmente, no cobáio, em 3 dias, e observaram ser a $L$. canicola menos patogênica que a L. icterohaemorrhagiae.

JUNGHERR (1937), em Conecticut (U.S.A.), referiu-se a uma epizootia por leptospira, na qual dentre 42 cães infectados, salvou-se um.

REITER (1935), determinou a natureza infecciosa da leptospira para a Gastro-enterite Hemorrágica dos cães. 
PETERSEN e JACOBSEN (1937), em cães de Gislev (Dinamarca), verificaram soro-aglutinação em 19 (35,7 por cento) de 53 casos estudados.

DAHR (1937), em cães de Colônia (Alemanha), em um total de 250 animais, encontrou 4 por cento positivos para soro-aglutinação.

SARDJITO, MOCHTAR e WIRASMO (1937), de 129 exemplares de Rattus rattus brevicaudatus, procedentes da ilha de Java, isolaram 23 amostras de leptospiras, as quais apresentaram pouca virulência para o cobáio e muito patogênicas para a marmota, produzindo icterícia neste animal. ESSEVELD e MOCHTAR, classificaram estas amostras como uma nova espécie $L$. javanica.

KUBO e KITAOKA citados por BADUDIERI e CASTAGNOLI (1940), pesquisaram a leptospira em rins de 122 cães, usando o processo do fundo escuro e, em 7 casos (5,7 por cento), obtiveram resultados positivos, sendo que 4 amostras foram identificadas como L. icterohaemorrhagiae.

SCHÜFFNER e WALCH-SORGDRAGER (1938), na Holanda, estudando infecção por leptospira em 26 cães, verificaram que em 13 casos os soros aglutinavam $L$. canicola e, em 9 casos, $L$. icterohaemorrhagiae.

VANDER WALLE (1938), em 100 cães de Amberes (Bélgica), verificou 29 casos positivos para a $L$. canicola e 15 para a $L$. icterohaemorrhagiae.

MEYER, EDDIE e STEWART (1938), pesquisaram a leptospira em 67 cães da Califórnia (U.S.A.), vitimados por icterícia ou Gastro-enterite Hemorrágica. Em 6 animais (8,9 por cento), com icterícia, isolaram leptospira pouco virulenta para o cobáio. Estes mesmos autores em 1939, examinando 87 cães em São Francisco (U.S.A.), atacados de icterícia e Gastro-enterite Hemorrágica, isolaram 11 amostras classificadas como L. canicola.

PROKOPANOFF (1939), em 360 cães de Berlim (Alemanha), obteve 54 (15\%) de soro-aglutinação para leptospira.

OTTOSEN (1939), realizando estudos sorológicos em cães de Copenhague, encontrou em 589 animais enfermos, 260 casos positivos $(44,5 \%)$ e, em 197 aparentemente sãos, 55 (27,9\%), positivos. Na maior parte a soro-aglutinação foi positiva para L. canicola.

SNAPPER, CHUN, CHU e CHEN (1940), em Peiping (China), encontraram em 58 cães examinados, 5 casos (8.6\%), apresentando soroaglutinação positiva para $L$. canicola, $L$. hebdomadis e L. bataviae.
LUCREZI (1940), em Nápoles (Itália), em 100 cães encontrou 12 positivos para L. canicola. BABUDIERI e CASTAGNOLI (1940), Roma (Itália), obtiveram em 159 cães examinados, 57 $(35,9 \%)$ de soro-aglutinação positiva, sendo 2 para L. canicola, 1 para o tipo "Mezzano", 1 duvidosa para $L$. oryzeti $\mathrm{e}$ as restantes para a $L$. icterohaemorrhagiae.

RAVEN (1941), encontrou em 105 cães de diferentes lugares do Estado de Pensilvânia (U.S.A.) e em 50 da cidade de Filadélfia desse mesmo Estado, soro-aglutinação positiva em 38\% e $28 \%$, respectivamente.

SAVINO e RENNELLA (1944), em 390 cães da cidade de Buenos Aires (Argentina), verificaram, examinando os rins, 6 casos positivos, que pelas propriedades antigênicas e pouco poder patogênico para cobáios supuseram tratar-se de L. canicola.

A Leptospira canina, tem sido pouco estudada no Brasil, existindo a este respeito pequeno número de trabalhos executados.

DACORSO FILHO (1940), no Rio de Janeiro, conseguiu isolar pela primeira vez no Brasil, a $L$. icterohaemorrhagiae do cão e, reproduzir a doença por inoculação, em cães e cobáios.

AZEVEDO e SANTOS (1945), isolaram leptospiras de casos humanos e de cães, no Rio de Janeiro. De 8 cães examinados, num período de um ano isolaram 7 amostras de leptospiras, das quais 3 correspondiam a L. icterohaemorrhagiae e as 4 restantes, admitiram ser $L$. canicola. Os autores lamentaram não ter sido possível executar no momento, as provas sorológicas.

Em 1926, HAMILTON RICE citado por DACORSO FILHO (1940), efetuou trabalhos experimentais no Amazonas, demonstrando a viabilidade da infecção nos cães, bem como, a possibilidade de disseminar a doença em outros animais e, ao próprio homem.

Concluindo este capítulo, podemos firmar o conceito de Leptospirose, como sendo em nosso meio, uma doença infecciosa, aguda, produzida por dois microorganismos principais: $L$. icterohaemorrhagiae, que tem como reservatório natural o rato e $L$. canicola, cujo reservatório natural é o cão. Até o presente momento, não se demonstrou que o rato seja igualmente portador da L. canicola, ao contrário do que se verificou com o cão, que além de ser o reservatório da L. canicola, pode contrair e transmitir a $L$. icterohaemorrhagiae. 


\section{QUADRO CLÍNICO NO HOMEM}

Na sua forma clássica, tal como fora descrita por Weil, a doença se inicia por um período septicêmico, que pode durar até uma semana, durante a qual é possível isolar os agentes infecciosos da corrente circulatória.

Este período, como em todas as doenças infecciosas está caracterizado por febre elevada de tipo irregular, variando entre $38-40^{\circ} \mathrm{C}$, durante 5 ou 10 dias, notando-se bem abatido o estado geral do doente. A fase congestiva, pela qual atravessa, caracteriza-se pela cefalalgia e fotofobia. Há sede, anorexia, dores musculares, principalmente, nas panturrilhas. Neste período, é constante e presente a afecção renal, porque, neste tempo, estabelece-se a localização do microorganismo no parênquima renal. Neste primeiro septenário, período de invasão, os fenômenos subjetivos e objetivos não são característicos, simulando mais um estado infeccioso geral. No fim deste período, inicia-se o ataque ao parênquima hepático que se acompanha de leve subicterícia. O período seguinte é o da localização parasitária no parênquima hepático, também, chamado período ictérico ou tóxico, havendo nesta ocasião, o pioramento da função e da integridade renais. O período ictérico se caracteriza por apresentar uma icterícia do tipo infeccioso, com urinas colúricas e fezes coradas. Neste momento, perturbadas que estão as funções renal e hepática, o sangue retrata pelo seu estudo o quadro bioquímico da hepato-nefrite. A função excretora do rim se encontra diminuída ou ausente, produzindo por isso, azotemia de nível elevado.

Aliado ao fator renal da azotemia, somam-se os fatores extra-renais, conseqüentes à grande destruição de proteínas. A oligúria que se observa, contribui para o aumento da retenção do azoto. Como nas demais doenças tóxicas, observa-se aumento da sedimentação de eritrócitos, hiperleucocitose com aneosinofilia, neutrofilia com desvio para a esquerda e certa tendência à hipotrombinemia, com retração incompleta do coágulo. As hemorragias são freqüientes durante o período tóxico, sendo positiva a prova do laço. Aparecem epistaxis, hematemese, melena, hemorragias cutâneas, urinárias e subconjuntivas. Casos há, onde a hemorragia pode ser gastrointestinal, que sendo abundante, causará a morte. A afecção do miocárdio, traduzida por miocardite, causa graves transtornos do funcionamento do órgão, dando origem a modificações do E. C. G. o período tóxico, ictérico, corresponde à localização da leptospira no parênquima hepático e, no resto do organismo, sendo encontrado neste período, o agente etiológico na urina, ao mesmo tempo que se ausenta da corrente circulatória. A convalescência caracteriza o terceiro período da doença. Nesta ocasião, sobrevém uma poliúria que pode atingir a emissão de grande quantidade de urina nas 24 horas. Processa-se o desaparecimento do aspecto tífico em que se encontravam submergidos os pacientes. A pressão arterial atinge, paulatinamente, o nível normal, estabelecendo-se na face do paciente $\mathrm{o}$ aspecto vivaz em substituição ao de estupor, em que se encontrava por efeito da existência da intoxicação.

É comum observar-se entre alguns pacientes uma recaída no decorrer do período da convalescência, durante o qual apresentam febre na ausência de leptospiremia. A morte por Leptospirose ocorre devido à intoxicação intensa de que são acometidos os pacientes. Nota-se nesse período, que os indivíduos que são portadores de hepatopatias são os que menos resistem à infecção. Entretanto, nem sempre os casos de Leptospirose apresentam a sintomatologia geral das infecções, pois segundo se verificou em Porto Alegre, a doença não seguiu a seqüência típica em todos os casos, apresentando sintomatologia e evolução irregular, observando-se ainda, formas frustas e atenuadas. Num dos casos do qual foi possível isolar a primeira amostra do agente patógeno, o indivíduo apresentava-se francamente febril e, subictérico, trabalhando, entretanto nos afazeres de sua casa. Noutros casos, a icterícia aparecia mesmo na ausência de febre. No comum dos casos, os pródromos da doença eram os de uma gripe, acentuando-se a febre até o aparecimento da icterícia, mantendo-se elevada até que a crise se desencadeava com descargas urinárias.

Não deixaram de estar presentes, as formas cardiorenais, as quais foram, naquela epidemia, as causadoras da mortalidade, principalmente, entre os adultos.

Pudemos assim, em breves palavras mostrar duas das formas mais comuns da doença: a forma icterícia grave e a forma de icterícia catarral. Ao lado destas duas formas existem outras caracterizadas pelo estado infeccioso sem, entretanto, verificar-se a icterícia, coisa que precisamente aconteceu no Paraná, em 1946. 


\section{QUADRO CLÍNICO NO CÃO}

Ao lado dessas formas assinaladas no homem, poderemos descrever outras que se caracterizam por uma forma meníngea produzida pela $L$. canicola. Esta espécie é a responsável pela Doença de Stuttgart.

O cão a contrai, ao que parece, dos ratos, entretanto, pode não demonstrar sintomas da infecção e daí o perigo que oferece pela leptospirúria acentuada e o possível contágio ao homem e a outros animais.

Esta infecção é menos grave do que a devida à $L$. icterohaemorrhagiae sendo comuns as manifestações meningíticas da doença. A doença produzida pela $L$. canicola, conhecida em todo o mundo, pode existir sob forma enzoótica. Ao lado desta descrição que diz mais respeito ao homem, o cão igualmente, apresenta formas clínicas diferentes da doença. Assim, além da Doença de Stuttgart, o cão pode ainda apresentar as formas hepática e nefrítica. Na primeira delas, isto é, na Gastro-enterite Hemorrágica, o início da doença é brusco, recusando o animal os alimentos, tornando-se triste e abatido. A temperatura atinge $41^{\circ} \mathrm{C}$, apresentando o animal, uma fase catarral com as conjuntivas congestionadas e, com aparecimento de petéquias, principalmente, sobre a mucosa bucal. $\mathrm{O}$ aparelho digestivo, nesta modalidade de doença, é o ponto de eleição para a demonstração dos sintomas. Preponderam aí, as hemorragias caracterizadas por diarréias e hematemeses. Em conseqüência da anúria que se estabelece, o animal entra, facilmente, em azotúria, morrendo em estado de coma. Na forma de comportamento hepático, o animal se apresenta com toda a sintomatologia do estado toxêmico, coisa que é seguida pela icterícia que se estabelece após 4 ou 5 dias de decorrida a doença. O estado tóxico estabelecido e a conseqüente lesão renal que o segue, serão as causas imediatas da morte do animal, por azotemia. Poder-se-ia descrever a forma nefrítica, separadamente da hepática, porém, as duas estão tão relacionadas que se torna impossível descrevê-las, pois o mecanismo de morte resulta sempre da imperfeita eliminação dos produtos tóxicos elaborados pela desagregação de substâncias protéicas. Nos casos típicos da Doença de Stuttgart, o início se caracteriza por profundo abatimento do animal, que mostra sede, apresenta vômitos e está possuído de grande prostração. A mucosa bucal, no desenvolvimento da doença e após os fenômenos de sequidão das mucosas a que ficam sujeitos os animais, apresenta a língua recoberta por um induto seco, que por vezes, dá lugar a ulcerações. Este estado, caracterizado como estado tífico, é consequiência da fase tóxica da doença. As ulcerações tornam-se muito extensas em alguns casos e daí o mau cheiro que pode exalar dos animais nessas condições. Este estado de coisas parece atingir todo o aparelho digestivo, pois o animal sente dores no abdômen e, os intestinos se apresentam espasmódicos. Nesse período, as fezes do animal são sanguinolentas, sendo a defecação dificultosa. Alguns dos órgãos nobres do animal, sofrem as conseqüências da infecção, contando-se o coração que quase sempre é a sede de miocardite tóxica, entrando em debilidade e arritmia.

Determinações puderam ser feitas por MONLUX (1948), que observou as principais variações químicas do sangue na Leptospirose Canina, verificando que o nitrogênio não protéico, o uréico e a creatinina, encontravam-se elevados durante a doença, bem como o fósforo inorgânico.

A urina dos animais doentes é geralmente clara a princípio, tornando-se de cor âmbar ou escura quando aparece a icterícia, podendo a densidade atingir a cifras altas. A reação da urina é de modo geral ácida, no período da doença, tornando-se, entretanto, alcalina quando o animal é passível de prognóstico favorável. Os animais apresentam forte albuminúria, principalmente durante $\mathrm{o}$ período de icterícia e, ainda, conseqüente ao comprometimento hepático que se estabelece. Aparece aí para mais de $2 \mathrm{~g}$ de albumina, sendo o sedimento urinário acompanhado de todos os elementos satélites encontrados nas nefrites (cilindros, hemátias, células renais, etc.). Embora, as urinas não possuam açúcares nesta doença, aparecem entretanto, algumas substâncias capazes de reduzir os reagentes da glicose e, este aumento de substâncias redutoras aparece durante as duas primeiras semanas da moléstia. A contagem global de eritrócitos parece não ter modificações apreciáveis, havendo, entretanto, tendência para diminuição dos mesmos. A hemoglobina parece correr parelha com à contagem de hemátias ou ainda, conseqüentes a causa que não à doença. Entretanto, a contagem de leucócitos varia entre grandes limites, podendo atingir a cifras altas, quando grave for o estado do animal. Existe neutrofilia que se inicia no terceiro dia da doença, atingindo o máximo no oitavo dia.

Os estudos levados a efeito sobre a fórmula leucocitária demonstraram a presença de forte 
neutrofilia, com aumento de formas em bastão e de formas jovens, o que equivale dizer que existe nestes casos uma inversão do índice de Arneth e Vélez, bem como aumento do índice de Schilling. A hemo sedimentação, pode ser o meio indicado na Leptospirose Canina, para determinar o estado geral do animal e a evolução da doença.

Nos estudos levados a efeito por MONLUX (1948), a sedimentação é muito precoce na doença experimental. A sua significação é tão importante que basta a sedimentação da primeira hora para que se tenha o provável diagnóstico. $\mathrm{O}$ índice de sedimentação é indicador da evolução da doença, tendo por conseguinte, grande valor no diagnóstico; pois, um animal, cuja doença se assemelha à Leptospirose, se não apresentar um índice de sedimentação elevado, não se tratará, certamente, da infecção. A duração média da doença é de 8 a 10 dias, de acordo com a gravidade dos sintomas, de maneira que a morte pode ocorrer desde o terceiro dia e, excepcionalmente até uma semana. A morte sobrevém quando o animal se acha em estado de coma urêmico, seguido por vezes de espasmos clônicos. Todos os casos em que a doença se estabelece, rapidamente, acarretando prostração profunda, diarréia e aumento exagerado de uréia no sangue, o prognóstico é sempre mau. A idade do animal é naturalmente elemento de prognóstico, pois sabemos que os animais jovens são capazes de suportar melhor a doença do que um adulto ou velho.

\section{QUADRO CLÍNICO NOS ANIMAIS DE INOCULAÇÃO}

O cobáio é o animal mais suscetível à infecção experimental pela L. icterohaemorrhagiae e, como tal, a sintomatologia assemelha-se muito ao que ocorre na espécie humana. Os sintomas resumemse em febre, icterícia e hemorragias. Em alguns casos, a febre parece acompanhar o desenvolvimento da doença, desde o primeiro dia da inoculação. Entretanto, supõe-se que a febre inicial correrá por conta do choque, em se tratando de animal inoculado com proteínas estranhas. $\mathrm{O}$ animal inoculado permanece triste desde $o$ primeiro dia da inoculação, porém, alimenta-se. Do momento que se inicia a febre resultante da infecção, o animal permanece triste e de pelos eriçados, refugando a alimentação.
Nessas condições, a temperatura pode atingir $40^{\circ}$ $\mathrm{C}$ ou mais, quando tomada a temperatura retal. Nota-se, igualmente, nessa ocasião, ligeira congestão das mucosas, principalmente, a ocular. A partir do quinto dia da inoculação, as conjuntivas e as partes descobertas do corpo do animal, principalmente, nos albinos, observa-se palidez e presença de subicterícia discreta, que se acentua, à medida que se opera o derrame biliar. Nessa fase, o animal, apresenta-se inteiramente abatido, permanece quieto, tristonho como que entorpecido. Geralmente o animal morre a partir do sexto dia e, não raras vezes, apresenta sinais de hemorragias nasais, vulvares e anais. A icterícia que acomete os animais em tais condições, depende do grau de lesão hepática e, em certos casos, extremamente intensa, coincidindo quase sempre com uma queda brusca de temperatura, após o que sobrevém a morte.

A coloração amarela atinge todos os tegumentos, sendo principalmente, observada nas partes descobertas do animal. Os elementos dependentes do comportamento renal, estão presentes na urina, encontrando-se cilindros, albumina, colúria, hemátias e, principalmente, os elementos patógenos com relação à doença. $\mathrm{O}$ comprometimento da suprarrenal, justifica a adinamia tóxica que se observa nos animais, a qual é progressiva e fatal. $\mathrm{O}$ comprometimento inflamatório e tóxico sobre a fibra cardíaca, contribui, finalmente, para o débâcle cardíaco e, a sua debilidade chega a tal ponto que a própria manipulação do animal pode provocar a morte.

\section{ANATOMIA PATOLÓGICA}

As lesões macroscópicas no homem e nos animais, caracterizam-se pela presença de hemorragias petequiais e, menos comumente, equimóticas, espalhadas pelo corpo. Quando presente a icterícia, a necropsia revela uma intensa coloração amarela ouro, que atinge todo o organismo. Contrasta, perfeitamente, a cor amarela das inúmeras petéquias espalhadas pelo corpo.

As lesões hemorrágicas são preponderantes nos pulmões, onde se apresentam sob a forma de equimose, sendo observadas, também, na vesícula biliar, cérebro, músculos e, às vezes, em quase todos os órgãos do animal. A hemorragia é muito comum nas regiões inguinal e axilar, não sendo, entretanto, visível, perfeitamente, nos animais de pele pigmentada. Em síntese, podemos afirmar que as principais modificações patológicas da 
Leptospirose, dependem, em última análise, do grau de icterícia, do índice de azotemia e das modificações acarretadas pelo próprio microorganismo que se localiza nos órgãos após a fase septicêmica. Por esse motivo, as lesões estão representadas por hemorragias em quase todos os órgãos, de preferência nas serosas, tubo gastrointestinal, pulmões, suprarrenais, rins e, especialmente, músculos voluntários.

Conseqüente à icterícia, todos os órgãos ficam corados pela bilirrubina, e em alguns casos, segundo a intensidade da mesma, apresentam a coloração amarela-avermelhada.

$\mathrm{O}$ fígado por vezes, mantém-se em volume, porém, noutras ocasiões, encontra-se aumentado, e o seu parênquima está corado de amarelo pela bilirrubina. O baço, aparentemente, é normal, enquanto os rins são os órgãos mais atingidos pela doença e, assim, apresentam-se, freqüentemente, aumentados no seu volume, amolecidos, pálidos e corados pela bilirrubina, com hemorragias intraparenquimais, separando perfeitamente, a cápsula da medula. Microscopicamente, as lesões obedecem as mesmas causas que as lesões macroscópicas. O fígado por exemplo, pode não oferecer o aspecto de camurça que lhe emprestou a doença, nos casos estudados por NOGUCHI.

Os fenômenos hemorrágicos se apresentam não somente na pele como também, nas serosas e mucosas. A traquéia e os brônquios apresentam, também, hemorragias. Não raro, encontram-se focos hemorrágicos no tecido conjuntivo peritraqueal, especialmente, entre a traquéia e o esôfago, bem como na pleura e na parte superficial externa do pulmão. $\mathrm{O}$ aspecto que apresenta este órgão em face das lesões hemorrágicas, deu a esta doença uma característica que conforme estudos de PETTIT, é reconhecida como grande auxiliar no diagnóstico anatômico da Doença de Weil. Esta característica traduz-se por pequenas hemorragias puntiformes espalhadas por toda a superfície do órgão, dando-lhe o aspecto de asa de borboleta ou melhor, de pele de tigre, donde surgiu o nome de pulmão em "asa de borboleta" ou "pulmão tigrado". O aparelho digestivo também, apresenta numerosos pontos de hemorragias no interior da cavidade gastro-entérica. Encontra-se por esse motivo, líquido sanguinolento no estomago e nos intestinos, e a mucosa desses órgãos se apresenta de aspecto hemorrágico puntiforme ou mesmo, com grandes sufusões em toda a sua extensão. Os folículos linfóides do intestino apresentam mobilização evidente com aumento das placas de
Peyer, consequiente à reação histio-linfocitária que se processa. O fígado como já tivemos ocasião de nos referir pode demonstrar-se acamurçado, não estando tumefeito nem pálido, porém, mais friável do que o normal, com hemorragias petequiais na cápsula. O sistema de condutos hepáticos evidencia a presença de pequenas hemorragias. Muitas vezes, a vesícula biliar é encontrada bastante distendida, acumulando bile de cor clara ou mesmo sanguinolenta.

$\mathrm{O}$ parênquima pancreático bem como o tecido conjuntivo intersticial apresentam como os demais órgãos, fenômenos hemorrágicos. Os rins se mostram pálidos, levemente amarelados, tumefeitos e hemorrágicos no seu interior. Numerosas petéquias podem ser observadas na cápsula renal e nas zonas cortical e medular, que via de regra, não permitem a distinção entre estas duas últimas.

Ocasionalmente, pode acontecer que se depare com maior irrigação sanguínea em uma delas, principalmente, na medular, em contraposição à cortical que permanece pálida. $\mathrm{O}$ baço, como órgão retículo-endotelial e integrante dos elementos de defesa do organismo, reage por hiperplasia. Apresenta-se hemorrágico, friável e na cápsula nota-se regular quantidade de petéquias.

O timo sofre, também, a ação tóxica da doença, apresentando focos hemorrágicos bem como, modificações na sua consistência e no volume, que se torna menor, sofrendo regressão. Na glândula suprarrenal, notam-se intensas hemorragias tanto na zona medular como na cortical. Histopatologicamente, as transformações correm proporcionais às modificações macroscópicas encontradas nos diferentes órgãos. As principais lesões são: a hemorragia $\mathrm{e}$ as conseqüentes degenerações que sobrevêm.

Nos pulmões, as hemorragias são focais e, sempre em torno dos vasos que atravessam o parênquima. $\mathrm{O}$ aspecto emprestado à região é de um foco pneumônico dada a grande quantidade de pontos hemorrágicos, simulando assim, hepatização do tipo pneumônico, pois é grande a quantidade de elementos do sangue que são encontrados nos alvéolos. As paredes dão origem a mobilização dos elementos, que pouco a pouco, invadem o parênquima pulmonar e se transformam em grandes macrófagos que contêm hemátias e pigmentos fagocitados. $\mathrm{O}$ miocárdio aparentemente normal, apresenta focos petequiais e hiperemia dos capilares. As petéquias estão situadas no tecido intersticial do miocárdio, 
principalmente, do lado endocárdico. Torna-se claro o estado de edema em que se encontram as fibras musculares onde estão presentes elementos provenientes do sangue.

O fígado é o órgão que sofre as maiores modificações de ordem histopatológica. Nele, os microrganismos são encontrados em quantidade grande. As traves de Remak são os elementos que sofrem modificações estruturais que retratam vasto desarranjo de organização de seus elementos celulares. É tamanha a desorientação que o lóbulo hepático perde a disposição radiada que , normalmente, se observa em direção à veia centrolobular. Conseqüentemente, os elementos celulares sofrem modificações metabólicas traduzidas por infiltrações e degeneração gordurosa bem como, impregnação de bile.

Os elementos celulares sofrem além da infiltração e degeneração gordurosa, processos de condensação cromática junto à membrana nuclear. Observa-se por vezes a hialinização celular que presta ao quadro histológico um aspecto salpicado de elementos acidófilos. Estas células assim degeneradas são encontradas em toda a espessura do lóbulo hepático. Nota-se, igualmente, hiperplasia Kupferiana, havendo acentuada eritrofagia.

As lesões renais caracterizam-se por estarem assentadas nos epitélios dos túbulos contortos. Observa-se aí degeneração hialina, tumefação turva. Estas modificações acarretam o desprendimento dos referidos epitélios aparecendo na urina os cilindros granulosos, hialinos, etc. Ao lado do processo degenerativo, observam-se lesões hemorrágicas que se localizam nos próprios túbulos, como também, nas próprias alças glomerulares.

\section{BACTERIOLOGIA}

As leptospiras oferecem particularidades dignas de nota. Foram INADA e IDO os primeiros a conseguirem culturas em meio de Noguchi, demonstrando que a temperatura ótima variava entre 22 a $25^{\circ} \mathrm{C}$.

As principais exigências nutritivas de todos os componentes do gênero, são uma baixa concentração de produtos derivados das proteínas em meio líquido ou semi-sólido com soro e, comumente, traços de hemoglobina.

PETTIT (1928), afirmou que as leptospiras acostumadas ao meio de cultura, poderão permitir repicagens continuadas durante longo espaço de tempo. O pH 7,4-7,6 é uma das condições essenciais para o cultivo "in vitro". Este mesmo autor verificou que a $L$. icterohaemorrhagiae, pode variar de comprimento, pois, no organismo do camundongo mede 6-7 micra; em meio com base de soro de coelho é de 12-15 micra; em soro de asno chega a atingir 120-150 micra.

GUIDA (1949), efetuou um estudo sobre os meios de cultura empregados, no isolamento de raças novas. Para isso, utilizou vários meios, entre eles o de Verwoort, Luchang e Fletcher, concluindo que o primeiro é o mais adequado ao isolamento das leptospiras, com 91,76 por cento de culturas positivas.

AZEVEDO e SANTOS (1945), utilizaram-se do meio de Noguchi-Wenyon, para o isolamento da leptospira, achando que o de Verwort-Schüffner é o meio que melhor se presta para o preparo de antígenos.

Os meios de Reiter e Ramme, e Noguchi, foram utilizados por NEVES (1942), no isolamento das amostras provenientes da epidemia verificada em Porto Alegre.

Outros elementos foram utilizados para o cultivo da leptospira, utilizando-se os soros humanos e de cavalo, obtendo-se com eles os mesmos resultados do que os obtidos com o soro de coelho. As culturas de leptospira são difíceis de se manterem vivas e, com vitalidade longa, porém, em determinadas condições, são capazes de permanecerem utilizáveis, durante longo tempo. Dentre outros fatores que atuam sobre as culturas de leptospiras, temos a dessecação do meio pela evaporação da água, tornando mais densas, coisa que abrevia muito a longevidade das culturas. É recomendável, devido esta circunstância, que todas as culturas sejam mantidas à temperatura ótima, em tubos perfeitamente arrolhados.

Sabemos que as leptospiras se adaptam aos meios de cultura e uma vez mantidas dentro das normas do cultivo, as raças poderão permanecer muito tempo vivas e com vitalidade.

Nos meios líquidos, uma ou ambas as extremidades se curvam em forma de ganchos semi-circulares, que abrangem $1 / 10$ a $1 / 8$ do microorganismo. Neste meio, apresentam os três movimentos característicos: flexão, rotação e translação, enquanto que nos meios semi-sólidos de agar, possuem movimentos uniformes, tanto para frente como para trás. Só são visíveis quando vivas em campo escuro. Coram-se pelo Giemsa e pela impregnação com a prata. 
Anticorpos desenvolvem-se precocemente, no doente, após uma semana destes, o mais importante são lisinas. O soro sanguíneo misturado à leptospira, em presença de complementos, determina a lise rápida dos microorganismos.

Uma imunidade duradoura segue-se à Doença de Weil e parece provável que todas as leptospiroses deixem uma resistência duradoura à infecção subseqüente.

Comumente, recomenda-se isolar o germe a partir do sangue circulante, na época septicêmica, no primeiro septenário. A inoculação de sangue venoso no peritônio de cobáios jovens, produz nesse animal um quadro de icterícia hemorrágica mortal, no fim de 5-6 dias após a inoculação.

A pesquisa bacterioscópica direta, do sangue ou da urina do paciente, diretamente, em campo escuro, cortes de órgãos (fígado e rim), corados pelo método de LEVADITI, podem dar ótimos resultados de diagnósticos bacteriológicos.

A semeadura de sangue (2-3 ml), desfibrinado em meio de Fletcher, Noguchi-Wenyon, VerwoortSchüffner é, também, altamente recomendável.

Sendo as leptospiras eliminadas pelas vias urinárias dos animais doentes e portadores naturais, contaminam o solo, a água e os alimentos, onde se conservam vivas durante 6-7 dias, sendo que em condições favoráveis, isto é, águas estagnadas, lama dos canais e margens dos riachos lentos, podem viver, saprofiticamente, durante um tempo considerável.

BUCHANAN (1927), afirmou terem as urinas ácidas, uma ação lítica sobre as leptospiras, fazendo-as desaparecerem do meio.

\section{ANIMAIS DE INOCULAÇÃO}

Os cobáios são os animais de escolha para a reprodução experimental da doença. Estes animais são sensíveis à inoculação intra-peritonial, de macerado de órgãos ou sangue de leptospirósicos.

MONLUX (1948), trabalhando com vários animais como cães, gatos, suínos, ovelhas, ratos brancos, galinhas e hamsters, concluiu que as amostras de leptospira utilizadas, mantiveram-se vivas somente em cães, hamsters e cobáios, sendo que os hamsters apresentaram um grau de sensibilidade maior que os cobáios, para o estudo da reprodução experimental da doença, sendo, também, o curso da doença mais rápido $\mathrm{e}$ característico.

O hamster morre em 4 dias, ao passo que o cobáio resiste até o sexto dia. Por esse motivo, o hamster, torna-se o animal mais próximo para o isolamento do microorganismo.

LARSON (1914), verificou que os camundongos tem a particularidade de evidenciarem a icterícia, que é melhor observada nas orelhas e plantas dos pés, e a infecção pode, igualmente, ser diagnosticada por outros sintomas típicos, numa proporção bem elevada $(97,9 \%)$.

Para uma perfeita determinação, deve-se utilizar, para cada reação, pelo menos 3 camundongos, efetuam-se as pesquisas complementares. A icterícia em alguns camundongos começa a ser visível no geral, depois do quarto dia da inoculação.

DEANE (1946), julgou ser muito breve a bacteremia, sendo por esse motivo, negativas as pesquisas feitas no sangue dos camundongos inoculados. A morte sobreveio, a partir do quarto dia. Os animais que sobreviveram à infecção, tornaram-se portadores, pois eliminavam leptospiras até 3 meses após a inoculação.

\section{MÉTODOS DE DIAGNÓSTICO}

Os métodos de diagnósticos repousam em primeiro lugar, no diagnóstico clínico que permite diferenciar de outras entidades mórbidas que se assemelham pelo quadro ictérico e, que são capazes de ser confundidas com a Doença de Weil e a Doença de Stuttgart.

Vários métodos foram propostos para a pesquisa do índice de infecção em ratos, porém, até o presente momento, não se estabeleceu uma norma padrão de investigação, decorrendo disso, os resultados discordantes obtidos pr numerosos investigadores.

1) Métodos Simples:

a) Direto - exames em campo escuro, de urina ou emulsão renal. Pesquisas em cortes histológicos pela impregnação argêntica (método de LEVADITI, método de FONTANA, modificado por MOROSOW, método de MADUREIRA PARÁ).

b) Indireto - inoculação em animais de laboratório, por via intraperitonial sangue de doentes - emulsão de rim cultura de emulsão de rim em veia apropriada (Verwoort-Schüffner, Noguchi-Wenyon, Fletcher, etc.). Provas sorológicas. 
2) Métodos Mistos - cultura - inoculação histológico - microscópico.

GUIDA e MONICI (1949), nos estudos comparativos de vários métodos de pesquisas em ratos, concluíram que:

1) Entre os métodos simples, o de cultura é o mais favorável.

2) O método de inoculação em cobáios é prático e revela um número bem aproximado de ratos portadores.

3) A associação desses dois métodos simples, apresenta um resultado favorável.

4) A combinação dos métodos microscópicos - cultura - inoculação e microscópico histológico - inoculação, é favorável ao estudo da incidência em ratos portadores.

Dos métodos descritos acima, as provas sorológicas são as que permitem determinar, de forma precisa, os portadores de leptospira.

Para um resultado satisfatório de aglutinação é necessário que se obtenha uma cultura de leptospira, não aglutinável espontaneamente.

Deve-se, por conseguinte, transferir, semanalmente, leptospira em constante crescimento para novos meios de cultura, não apresentando aglutinação espontânea.

O meio de Verwoort-Schüffner, parece ser o mais indicado para a manutenção das culturas, pesquisas de laboratório, preparo de antígeno e produção de soros aglutinantes. $\mathrm{O}$ animal escolhido para o preparo do soro aglutinante é o coelho que não deve possuir propriedades aglutinantes inespecíficas para a leptospira.

Inicialmente, a leptospira cresce mal, quando recém-isolada em meios de cultura, porém, algumas amostras são capazes de se desenvolverem bem. Estas repicadas, darão bom antígeno.

A determinação pela soro-aglutinação, far-se-á, colocando o soro suspeito diluído, em presença de cultura de leptospira; no caso contrário, fazer atuar sobre uma amostra do microorganismo, um soro aglutinante preparado de acordo com a técnica em coelho.

$\mathrm{O}$ isolamento do germe, a reprodução da doença experimental, o estudo anátomo-patológico dos órgãos atingidos pela doença, a soro-aglutinação e a pesquisa do microorganismo nos órgãos, são os elementos bases de confirmação ou inafirmação de um diagnóstico clínico de suspeita.
A pesquisa do microorganismo nos cortes ou em esfregaços, representam elementos auxiliares de muito valor no diagnóstico; a sua pesquisa está baseada nas propriedades dos microorganismos de reduzirem os sais de prata, uma vez sensibilizados pelos mordentes. Várias técnicas foram, especialmente, aplicadas para a pesquisa dos microorganismos nos cortes histológicos. Dentre as melhores, citaremos as de MADUREIRA PARÁ, LEVADITI, FONTANA, esta modificada por MOROSOW, sendo esta última, indubitavelmente, a de escolha, tendo-se em vista a facilidade de execução da técnica e a clareza como demonstra a leptospira.

\section{PARTE EXPERIMENTAL}

\section{MATERILA E MÉTODOS}

Orientamos nossas pesquisas com o fito de assinalarmos a presença de leptospiras nos principais animais portadores, ao nosso alcance e assim, podermos avaliar o índice de ocorrência desse agente patógeno.

Iniciamos com esse fim, a captura de ratos na zona central de Curitiba, bem como, nos perímetros urbano e suburbano, e, também, nas zonas rurais, onde se verificou uma epidemia da Doença de Weil, MIRANDA (1946).

Nossas pesquisas foram efetuadas ainda, em suínos, com o objetivo de verificarmos a possível ocorrência de leptospiras, visto que, SAVINO e RENNELLA (1944), na Argentina, isolaram amostras antigênicas diferentes, as quais denominaram de L. suis e L. hyos.

Cães capturados nas ruas desta Capital e suínos abatidos nos principais matadouros locais, foram igualmente, submetidos a exame. Os ratos e suínos foram sacrificados pelo método de sangria a branco, sendo que os cães, foram mortos segundo a técnica indicada por SAVINO e RENNELLA (1954), injetando-se, por via endovenosa, uma solução aquosa de sulfato de magnésio, a 50 por cento. De todos os animais abatidos, retiramos os rins para a pesquisa da leptospira. Uma vez submetidos os rins à esterilização de superfície por cauterização, eram puncionados de maneira a se obter a maior quantidade possível de parênquima, conservado à temperatura ambiente do laboratório. Todos os tubos semeados, foram examinados sistematicamente, a partir do terceiro dia, época que nos pareceu mais propícia à verificação das 
positividades. Os rins de cada animal, uma vez puncionados para cultura, eram triturados num gral, com areia esterilizada, sendo o material resultante, inoculado em cobáios jovens.

Todos os animais inoculados, foram mantidos em gaiolas separadas, e observados diariamente, afim de ser surpreendida a positividade, antes da morte do animal.

Este cuidado foi motivo de preocupação, pois que, desejávamos isolar amostras típicas do agente infeccioso, afim de prepararmos antígenos para as provas de aglutinação a serem levadas à cabo em trabalhos posteriores.

Uma vez manifestada a doença no cobáio, averiguada através de suas características clínicas, como sejam, febre e vários graus de icterícia, eram os animais sacrificados por embolia gasosa. Os principais órgãos capazes de albergar o microorganismo, tais como rins, fígado, suprarrenal e medula óssea, foram puncionados, e os materiais obtidos, semeados em meio de Wenyon foram examinados em fundo escuro, a partir do terceiro dia da semeadura.

A urina dos cobáios sacrificados ou mortos pela doença foi examinada em fundo escuro, afim de se verificar a presença da leptospira.

Todos os órgãos, inclusive os puncionados foram conservados em solução de formol a 10\%, para subseqüentemente submetê-los a exames histopatológicos e, pesquisa do agente patógeno pela impregnação argêntica.

Uma vez fixado o material, foi este incluído em parafina e cortado na espessura de 5 micra, sendo depois corado pela hematoxilina-eosina para os estudos histo-patológicos e, impregnados pela prata, segundo a técnica de MADUREIRA PARÁ (1946), para a pesquisa de leptospira nos cortes de blocos incluídos em parafina.

\section{MÉTODO DE MADUREIRA PARÁ}

\section{SOLUÇOES:}

Nitrato de urânio - solução aquosa a 1\%. Esta solução é estável à temperatura ambiente.

Nitrato de prata - solução a 1,5\%. Esta solução deve ser preparada, recentemente, e guardada na obscuridade à temperatura ambiente.

Carbonato de prata - aquecer uma solução aquosa de nitrato de prata a $0,2 \%$, até a ebulição, e juntar $2 \mathrm{ml}$ de uma solução aquosa de carbonato de lítio saturada a frio. A solução de carbonato de lítio deve, de preferência, ser preparada com alguma antecedência. Aquecer a mistura, gradualmente, e deixa-la ferver durante 1 ou 2 minutos. A solução opalescente resultante, é passada através de um papel de filtro e, o filtrado claro obtido é guardado num refrigerador onde se conserva no máximo até 30 dias.

Colofônia - solução a $5 \%$ de colofônia em álcool absoluto. Esta solução se conserva no refrigerador.

Redutor de Levaditi - ácido pirogálico ....4,0 g formol puro ........ $5 \mathrm{ml}$ água destilada .. $100 \mathrm{ml}$

\section{TÉCNICA:}

1- Cortes de blocos incluídos em parafina são feitos com a espessura de 4 a 6 micra, desparafinizados e hidratados segundo as técnicas usuais.

2- Colocar os cortes na solução de nitrato de urânio, onde devem permanecer pelo espaço de 30 minutos à temperatura ambiente.

3- Lavar, rapidamente, em água destilada.

4- Tratar os cortes durante 2 horas, na estufa a $56^{\circ} \mathrm{C}$, com solução de nitrato de prata, renovando a solução argêntica no fim da primeira hora. Noutra alternativa os cortes podem permanecer durante uma noite na mesma solução, à temperatura de $37^{\circ} \mathrm{C}$.

5- Lavar, rapidamente, em água destilada.

6- Transferir os cortes para a solução coloidal de prata lítica, onde permanecem durante 1 hora à temperatura ambiente. A solução é preparada num frasco de Coplin de $50 \mathrm{ml}$, pouco tempo antes do uso, de acordo com a seguinte fórmula:

solução aquosa de carbonato de prata lítica 45 $\mathrm{ml}$

solução alcoólica de colofônia a $5 \% 5 \mathrm{ml}$

A solução de colofônia deve ser juntada, rapidamente, à solução de prata; essa mistura deve ser agitada, levemente, resultando daí uma suspensão coloidal leitosa.

7- Transferir os cortes, diretamente, para o redutor de Levaditi, onde deverão permanecer à temperatura ambiente durante 10 a 15 minutos.

8- Lavar, rapidamente, em água destilada. 
9- Levar as lâminas ao microscópio para verificar se os cortes estão perfeitamente impregnados. Se não estiverem, tratá-los rapidamente, pelo álcool absoluto e repetir o tempo 6 durante 10 minutos, seguindose outra redução durante 5 a 10 minutos.

10- Desidratar e montar em bálsamo.

Se o tecido conjuntivo ou a ocorrência de precipitações, impedirem a boa impregnação, os cortes deverão antes de serem hidratados, passar do álcool a $70^{\circ}$ através da colofônia a $2 \%$, durante 2 horas, à temperatura ambiente, para a água e, em seguida, impregnados pela prata, segundo a técnica descrita.

O material restante foi cortado no micrótomo de congelação e impregnado pela prata, de acordo com o método indicado no trabalho de BONIFÁCIO COSTA et al. (1942) no qual MEDINA sugeriu a seguinte técnica:

\section{SOLUÇÕES:}

Nitrato de prata - solução aquosa de nitrato de prata a $2 \%$.

Redutor de Van Ermengen: ácido gálico .................... 7,0 g

tanino …......................... 3,5 g

acetato de sódio .............. 14,0 g

água destilada ................. $350 \mathrm{ml}$

\section{TÉCNICA:}

1) Cortar o material em congelação na espessura de 25 micra, fixado em solução de formol a $10 \%$, recebendo-se os cortes em água destilada.

2) Transferir os cortes com o auxílio de espátulas e suportes de vidro para a solução de nitrato de prata, que deverá ser aquecida a $60^{\circ} \mathrm{C}$ até que os cortes tomem a cor marrom.

3) Lavar, rapidamente, em água destilada.

4) Transferi-los para o redutor de Van Ermengen e, sob agitação do líquido, efetuar a redução.

5) Lavar e conservar na água destilada.

6) Colar os cortes com albumina, desidratar e montar em bálsamo.

Em ambos os processos o tecido impregnado apresenta as leptospiras em preto. Para o isolamento das leptospiras, o meio de Wenyon nos parece o mais propício e, mesmo mais acessível pela simplicidade de execução e pela grande facilidade que acarreta a verificação da presença do microorganismo.

\section{MEIO DE NOGUCHI-WENYON}

Misturar 1 parte de gelose simples a 2,5\%, com 9 partes de solução fisiológica alcalina $(\mathrm{pH}=7,4) \mathrm{e}$ estéril. Adicionar depois 20 gotas de sangue estéril de coelho para cada $10 \mathrm{ml}$ da mistura gelosesolução fisiológica.

Modo de preparar - A gelose e a solução fisiológica são aquecidas e misturadas. Distribuir na quantidade de $10 \mathrm{ml}$ e esterilizar de modo habitual. Resfriar o meio a $50^{\circ} \mathrm{C}$ e adicionar a cada tubo de $10 \mathrm{ml}$ de gelose-solução fisiológica alcalina, 20 gotas de sangue estéril de coelho sem mistura. O sangue do coelho é incorporado ao meio por deslizamento, sem agitar os tubos. Conservar o meio na geladeira até o momento de ser utilizado.

$\mathrm{O}$ exame em fundo escuro de uma gota do meio, permite observar facilmente, a presença das leptospiras em consequiência dos movimentos serpenteantes que possuem quando situadas no seio da massa semi-sólida, que constitui o meio de cultura. Elas aparecem iluminadas, com movimentos ativos em várias direções, preferentemente nos sentidos anterior e posterior. Uma vez libertadas da massa gelatinosa, adquirem, no meio líquido, a forma característica de $S$ ou $J$ e são dotadas de rápidos movimentos de rotação, os quais lhes emprestam a aparência de um 8 .

Nos estudos bacteriológicos do agente patógeno, empregamos outros meios de culturas, aconselhados por vários autores e, perfeitamente consagrados pela prática. Assim, tivemos a oportunidade de utilizar os meios de Packchanian, Fletcher, soro-água, Verwoort-Schüffner, Savino e Rennella, bem como, uma pequena modificação por nós introduzida no meio de Noguchi-Wenyon, constando da adição de $2,5 \mathrm{ml}$ de água destilada com hemoglobina de coelho à saturação.

Como nosso objetivo principal foi o isolamento do agente infeccioso, resolvemos empregar posteriormente, apenas o meio de Wenyon. Os meios que se destinam a ativar o crescimento da leptospira foram empregados para o preparo do antígeno. Pudemos observar que o meio de Wenyon oferece condições favoráveis ao crescimento abundantíssimo do microorganismo, uma vez que se superponha ao meio de Wenyon, 
2,5 $\mathrm{ml}$ de água destilada saturada de hemoglobina de coelho.

Foi-nos possível obter, assim, culturas de leptospiras dotadas de grande vitalidade e de sobrevida satisfatória, sem apresentar formas degeneradas.

As técnicas adotadas no presente trabalho foram escolhidas de acordo com o critério estabelecido por GUIDA e MONICI (1949). Estes autores demonstraram que os métodos simples mais propícios à determinação da $L$. icterohaemorrhagiae são, inegavelmente, da cultura e a inoculação. Logicamente, a combinação desses dois métodos fornece melhores resultados, pelo fato de terem ambos a seu favor maior quantidade de material em exame, o que faculta maior probabilidade de revelar a presença do agente patogênico.

Das técnicas mistas, e acima citada, é preferencial para estudos de tal natureza, porque o seu emprego, proporciona perspectivas mais amplas para se avaliar o índice de infecção que, aliás, é relativamente baixo, no Brasil.

Entre as demais combinações de técnicas simples, embora menos capazes de revelar a presença da leptospira, duas se sobressaem pela capacidade que tem de orientar o diagnóstico: o método histológico (impregnação argêntica de cortes) e o bacterioscópico direto em fundo escuro. Por esse motivo, acreditamos que a combinação das quatro técnicas simples (inoculação, cultura, exame histológico e bacterioscopia direta em fundo escuro), na dependência da diversidade do material em estudo, poderá fornecer de futuro, o índice real de infecção nos vários portadores de leptospiras.

Coadjuvamos o diagnóstico pelo exame anátomopatológico, sistemático, de todos os animais inoculados, quando mortos pela doença ou sacrificados em estado pré-agônico. Consideramos, os animais positivos para a Doença de Weil quando, além, de sub-icterícia ou icterícia franca, apresentavam hemorragias cutâneas, periganglionares, e ainda se encontravam presentes modificações características do chamado pulmão em "asa de borboleta". Microscopicamente, a nefrite hemorrágica e a desagregação das traves de Remak do fígado, foram consideradas como índice de possível positividade, na dependência da observação direta do agente patogênico por qualquer dos métodos empregados.

\section{RESULTADOS}

A) Isolamento, cultura e inoculação.

O quadro 1, apresenta o resultado geral das pesquisas procedidas em Curitiba e, demonstra que dos 50 ratos capturados, 49 pertenciam à espécie Rattus norwegicus (BERKENHOUT) e, 1 à espécie Rattus rattus (LINNAEUS).

A classificação destes roedores foi feita pelo Sr. CARLOS CELSO VIEIRA, do Departamento de Zoologia de São Paulo, ao qual expressamos os nossos agradecimentos.

Todos esses animais foram capturados e estudados nas mesmas condições.

O quadro 2, apresenta o resumo das técnicas empregadas e os resultados obtidos com as respectivas percentagens verificadas.

QUADRO 1 - RESULTADO DAS PESQUISAS DE LEPTOSPIRA NOS RATOS DE CURITIBA

\begin{tabular}{|l|c|c|c|c|c|}
\hline Rato & Espécie & $\begin{array}{c}\text { Local de } \\
\text { captura }\end{array}$ & $\begin{array}{c}\text { Inoculação } \\
\text { em cobáio }\end{array}$ & Wenyon & Resultado \\
\hline 1 & $\mathrm{Rn}$ & Curitiba & + & + & + \\
\hline 2 & $\mathrm{Rn}$ & Curitiba & - & - & - \\
\hline 3 & $\mathrm{Rn}$ & Curitiba & + & + & + \\
\hline 4 & $\mathrm{Rn}$ & Curitiba & + & + & + \\
\hline 5 & $\mathrm{Rn}$ & Curitiba & + & + & + \\
\hline 6 & $\mathrm{Rn}$ & Curitiba & + & - & + \\
\hline 7 & $\mathrm{Rn}$ & Curitiba & + & - & + \\
\hline 8 & $\mathrm{Rn}$ & Curitiba & - & + & + \\
\hline 9 & $\mathrm{Rn}$ & Curitiba & + & - & + \\
\hline 10 & $\mathrm{Rn}$ & Curitiba & + & - & + \\
\hline 11 & $\mathrm{Rn}$ & Curitiba & morreu & + & + \\
\hline 12 & $\mathrm{Rn}$ & Curitiba & + & - & + \\
\hline 13 & $\mathrm{Rn}$ & Curitiba & morreu & + & + \\
\hline 14 & $\mathrm{Rn}$ & Curitiba & - & - & - \\
\hline 15 & $\mathrm{Rn}$ & Curitiba & + & + & + \\
\hline 16 & $\mathrm{Rn}$ & Curitiba & - & + & + \\
\hline 17 & $\mathrm{Rn}$ & Curitiba & + & - & + \\
\hline 18 & $\mathrm{Rn}$ & Curitiba & morreu & + & + \\
\hline 19 & $\mathrm{Rn}$ & Curitiba & morreu & + & + \\
\hline 20 & $\mathrm{Rn}$ & Curitiba & + & + & + \\
\hline 21 & $\mathrm{Rn}$ & Curitiba & morreu & + & + \\
\hline 22 & $\mathrm{Rn}$ & Curitiba & + & + & + \\
\hline 23 & $\mathrm{Rn}$ & Curitiba & morreu & + & + \\
\hline 24 & $\mathrm{Rn}$ & Curitiba & morreu & + & + \\
\hline 25 & $\mathrm{Rn}$ & Curitiba & morreu & + & + \\
\hline 26 & $\mathrm{Rn}$ & Curitiba & - & - & - \\
\hline 27 & $\mathrm{Rn}$ & Curitiba & + & + & + \\
\hline 28 & $\mathrm{Rn}$ & Curitiba & + & + & + \\
\hline 29 & $\mathrm{Rn}$ & Curitiba & + & + & + \\
\hline 30 & $\mathrm{Rn}$ & Curitiba & - & - & - \\
\hline 31 & $\mathrm{Rn}$ & Curitiba & - & - & - \\
\hline 32 & $\mathrm{Rn}$ & Curitiba & - & - & - \\
\hline 33 & $\mathrm{Rn}$ & Curitiba & morreu & - & - \\
\hline 34 & $\mathrm{Rn}$ & Curitiba & morreu & - & - \\
\hline & & & & & + \\
\hline
\end{tabular}

(Cont.) 
QUADRO 3 - RESULTADOS DAS PESQUISAS DE LEPTOSPIRA NOS CAMUNDONGOS DE CURITIBA

\begin{tabular}{|l|c|c|c|c|c|}
\hline $\mathbf{N}^{\mathbf{0}}$ & Espécie & $\begin{array}{c}\text { Local } \\
\text { de } \\
\text { captura }\end{array}$ & $\begin{array}{c}\text { Inoculação } \\
\text { em cobáio }\end{array}$ & Wenyon & Resultado \\
\hline 1 & $\mathrm{Mm}$ & Curitiba & - & + & + \\
\hline 2 & $\mathrm{Mm}$ & Curitiba & - & + & + \\
\hline 3 & $\mathrm{Mm}$ & Curitiba & morreu & + & + \\
\hline 4 & $\mathrm{Mm}$ & Curitiba & morreu & + & + \\
\hline 5 & $\mathrm{Mm}$ & Curitiba & - & - & - \\
\hline
\end{tabular}

$\mathrm{Mm}=$ Mus musculus

$\mathrm{O}$ quadro 4 dá o resultado das pesquisas de leptospira, nos ratos da Colônia Agrícola Federal "Marquês de Abrantes", concluindo-se que de 10 ratos examinados, 9 eram da espécies Rattus rattus (LINNAEUS) e, 1 da espécie Oryzomys flavescens (WATERHOUSE), sendo este pertencente ao grupo dos ratos silvestres e um dos principais participantes das periódicas "ratadas" nos taquarais do Norte do Paraná e Sul de São Paulo, segundo CARLOS CELSO VIEIRA. Estes ratos apresentaram, com surpresa nossa, um índice negativo, apesar de ter sido aquela Colônia, sede do grave surto da Doença de Weil, por ocasião das "ratadas", em 1946, estudado por RUY NORONHA DE MIRANDA.

QUADRO 4 - RESULTADO DAS PESQUISAS DE LEPTOSPIRA NOS RATOS DE "MARQUÊS DE ABRANTES"

\begin{tabular}{|c|c|c|c|c|c|}
\hline Rato & 农 & 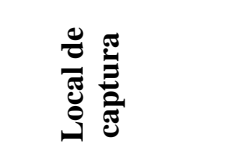 & 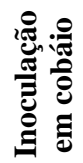 & $\sum^{\vdots}$ & 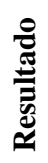 \\
\hline 1 & $\mathrm{Rr}$ & Marquês Abrantes & - & - & - \\
\hline 2 & Of+ & Marquês Abrantes & - & - & - \\
\hline 3 & $\mathrm{Rr}$ & Marquês Abrantes & - & - & - \\
\hline 4 & $\mathrm{Rr}$ & Marquês Abrantes & - & - & - \\
\hline 5 & $\mathrm{Rr}$ & Marquês Abrantes & - & - & - \\
\hline 6 & $\mathrm{Rr}$ & Marquês Abrantes & - & - & - \\
\hline 7 & $\mathrm{Rr}$ & Marquês Abrantes & - & - & - \\
\hline 8 & $\mathrm{Rr}$ & Marquês Abrantes & - & - & - \\
\hline 9 & $\mathrm{Rr}$ & Marquês Abrantes & - & - & - \\
\hline 10 & $\mathrm{Rr}$ & Marquês Abrantes & - & - & - \\
\hline
\end{tabular}

$\mathrm{Rr}=$ Rattus rattus (LINNAEUS)

Of $=$ Oryzomys flavescens (WATERHOUSE)

$+\quad=$ Destaca-se Oryzomys flavescens (WATERHOUSE), rato silvestre e um dos principais participantes das periódicas "ratadas" nos taquarais do Norte do Paraná e Sul de São Paulo (Carlos Vieira)

O quadro 5 apresenta o resultado de pesquisas de leptospira nos suínos procedentes de várias zonas do estado. Os resultados apresentaram-se negativos para um total de 153 suínos examinados.
QUADRO 5 - RESULTADO DAS PESQUISAS DE LEPTOSPIRA NOS SUÍNOS DO PARANÁ

\begin{tabular}{|l|c|c|}
\hline \multicolumn{1}{|c|}{ Procedência } & $\begin{array}{c}\mathbf{N}^{\mathbf{0}} \text { de animais } \\
\text { examinados }\end{array}$ & Resultado \\
\hline Araucária & 41 & Negativo \\
Laranjeira do Sul & 47 & Negativo \\
Cerro azul e Rio Branco & 25 & Negativo \\
Bocaiúva do Sul & 12 & Negativo \\
Curitiba & 28 & Negativo \\
\hline TOTAL & 153 & Negativo \\
\hline
\end{tabular}

O quadro 6 nos mostra as pesquisas efetuadas em cães de Curitiba, animais estes fornecidos pelo Serviço de Apanha da Prefeitura Municipal. Foram examinados 36 cães, que apresentaram resultados negativos, o que nos causou admiração, uma vez que temos conhecimento da existência, nesta Capital, de Gastro-enterite Hemorrágica, da qual vários casos foram confirmados pela evolução do quadro sintomatológico e exames de laboratório.

QUADRO 6 - RESULTADO DAS PESQUISAS DE
\begin{tabular}{|c|c|c|c|c|}
\hline $\mathbf{N}^{\mathbf{0}}$ & $\begin{array}{c}\text { Inoculação } \\
\text { em cobáio }\end{array}$ & $\begin{array}{c}\text { Macerado } \\
\text { de rim } \\
\text { examinado } \\
\text { em fundo } \\
\text { escuro }\end{array}$ & Wenyon & Resultado \\
\hline 36 & Negativo & Negativo & Negativo & Negativo \\
\hline
\end{tabular}

B) Observações Anátomo-Patológicas

Todos os animais inoculados com material proveniente de rato, que morreram em conseqüência da infecção leptospirósica ou que foram sacrificados no estado pré-agônico, apresentaram icterícia cuja tonalidade variava da amarela-clara à intensa. Os animais, principalmente os que não possuíam pele de pigmento escuro, permitiram a observação da icterícia a partir do quarto dia da inoculação, uma vez que a infiltração ictérica contrastava com a coloração normal do focinho, orelhas e períneo, e das regiões descobertas do corpo do cobáio. Observou-se, apesar disso, na pele depilada a formação de um pequeno pontilhado hemorrágico, quando se destacavam os pelos dos animais que iam ser sacrificados por embolia gasosa. Com a abertura da pele, o tecido celular subcutâneo apresentava-se intensamente amarelado, demonstrando com freqüência, em toda a espessura e superfície das zonas examinadas, a existência de hemorragias puntiformes, bem como, sufusões sanguíneas que se localizavam 
principalmente no tecido celular peri-ganglionar das regiões axilares e inguinais (fig. 1).

A alteração hemorrágica atingiu também os músculos, predominando a lesão nos órgãos abdominais, torácicos e músculos dos membros anteriores e posteriores.

$\mathrm{O}$ exame das cavidades buco-naso-faringeanas mostrou, em alguns dos animais examinados, a existência de hemorragias caracterizadas pela presença de uma substância intensamente mucosanguinolenta.

Os órgãos abdominais apresentaram hemorragias puntiformes, sufusões sanguíneas e hiperemia, sendo que, de modo particular, dentre outros, destacavam-se o fígado, baço, intestinos, suprarrenal e rins, que exibiam coloração amareloavermelhada conseqüente à impregnação ictérica concomitante.

Outrossim, encontramos hepatomegalia constante e o baço além de hipertrofiado, apresentava polpa extremamente friável e destacável como se observa em outras doenças infecciosas agudas.

A vesícula biliar, num dos animais que apresentava um quadro de intensa icterícia, estava repleta de bile, e mostrava intensas sufusões sanguíneas, sem que, contudo, houvesse sangue extravasado na bile.

A bexiga, além de hemorrágica, apresentava-se, na maioria das vezes, repleta de um liquido de cor amarela-citrina, cujo exame, em fundo escuro, demonstrou a presença de leptospiras.

$\mathrm{O}$ aspecto macroscópico dos pulmões seguiu a regra geral como órgão que oferece, na Doença de Weil, um quadro típico, constituído pelos aspectos que tomam os fenômenos hemorrágicos. Foi assim possível observar, em quase todos os animais vitimados pela infecção, intensas lesões hemorrágicas que emprestavam ao órgão o aspecto típico do pulmão em "asa de borboleta" ou "pulmão tigrado", dada a quantidade de petéquias e sufusões sanguíneas que recobriam a superfície do órgão (fig. 2).

O exame microscópico procedido na maioria dos órgãos e, principalmente, nos acima assinalados, indica que as principais lesões que aí se observam estão representadas pelas hemorragias intersticiais e parenquimatosas, bem como, pelos processos inflamatórios reacionais que sobrevém concomitantemente.

O quadro histo-patológico que se observa nos pulmões, está representado por focos hemorrágicos de pequeno e regular tamanhos que, localizados, espaçadamente, em todo o parênquima, chegam a ocupar número grande de alvéolos, emprestando à região o aspecto que se verifica na hepatização pulmonar, uma vez que a mobilização celular inflamatória, também toma parte no quadro patológico (fig. 3 e 4).

Entre os elementos que tomam parte ativa na mobilização celular, encontram-se células oriundas das paredes alveolares, interstícios conjuntivos e do sangue. Ao lado das lesões que se observam nos pulmões, o fígado contribui com características histológicas tidas como patognomômicas. Além das lesões de ordem hemorrágica e inflamatória, o desarranjo característico que se opera nas traves de Remak, empresta ao parênquima hepático uma desorientação arquitetônica de tal ordem, que não se vislumbra mais a radiação trabecular no sentido da veia centro-lobular (fig. 5).

As consequiências imediatas das perturbações metabólicas que aí têm lugar, acarretam transformações de ordem degenerativa. Observa-se assim, hialinização, infiltração e degeneração gorda, as quais podem atingir todas as células do órgão, sem que contudo afetem a disposição que se observa nas lesões produzidas pela Febre Amarela. $\mathrm{Na}$ suprarrenal, predominam as hemorragias, as quais são mais intensas na zona reticular e, menos pronunciadas, na cortical, onde os elementos celulares mostram grande número de vacúolos de vários tamanhos (fig. $6 \mathrm{e}$ 7).

Os rins, sede de grandes alterações, mostram focos inflamatórios parenquimatosos, degeneração hialina glomerular, tumefação turva dos "tubulicontorti", presença de cilindros, hemorragias intersticial e intratubular (fig. 8).

Os gânglios linfáticos, órgãos de função antixênica, exercem parte ativa nos processos de defesa, por uma intensa mobilização celular na qual tomam parte numerosos elementos redondos, entre os quais os de origem histiocitária, inclusive grandes macrófagos (fig. 11).

Os processos patológicos acima descritos, interessam diretamente o músculo cardíaco (fig. 10), o qual mostra, se bem que em menor grau, infiltração inflamatória intersticial e hemorragias. Excluindo o coração, todos os órgãos examinados revelaram, pelos processos de impregnação argêntica, a presença de leptospiras (fig. 9). Chamamos a atenção para o que observamos num dos casos examinados, no qual encontramos grandes novelos de leptospiras obstruindo a luz das glândulas intestinais, fato que nos leva a crer, 
que os intestinos representam também uma das vias de eliminação desses microorganismos.

\section{COMENTÁRIOS}

Compulsando a bibliografia ao nosso alcance, não deparamos com qualquer trabalho que revelasse o índice de leptospira nos murídeos, suínos e caninos, do Paraná.

Conseqüentemente, ao iniciarmos em agosto de 1949, a presente pesquisa, fomos compelidos a voltar nossa atenção para os ratos domésticos de Curitiba, por serem estes animais, os hospedeiros naturais dos microorganismos que mais interessam ao homem.

Assim, nos apresentou-se a oportunidade de estudarmos e adaptarmos as técnicas que deveriam ser empregadas para a execução desta pesquisa, bem como aquilatarmos a porcentagem de ratos portadores de leptospira, estendendo as pesquisas a cães e suínos, resultando disto, o interesse que tínhamos em confirmar, no primeiro caso, os trabalhos de vários autores nacionais, que admitem a existência de Leptospira canina, em nosso meio e, no segundo, verificar os estudos de SAVINO e RENNELLA (1944), que isolaram duas amostras de leptospira, denominando-as L. suis e L. hyos, cuja classificação temporária é baseada nos resultados obtidos em face dos caracteres antigênicos e biológicos.

No Brasil, GUIDA (1947-48), isolou três amostras de leptospiras num lote de 6 suínos, procedentes de Rio Claro.

Segundo vários autores, nota-se como fato interessante, que os índices de infecção dos ratos, variam dentro de grandes limites nas diversas regiões, onde se realizaram estudos sobre o assunto.

FORATTINI (1947), apresentou um mapa historiando os vários índices de infecção, em diversos países do mundo e, verificou que a maior incidência foi encontrada em Barcelona (Espanha), com $85 \%$, e em seguida, Washington (U.S.A.), com $47 \%$, porcentagem esta devida a LARSON, quem estudou e verificou o grau de incidência.

Os trabalhos de FORATTINI (1947), e GUIDA e MONICI (1949), são os que, atualmente, apresentam os maiores índices de infecção, dentre todos já realizados no País.

LARSON, GUIDA e MONICI, e FORATTINI, empregaram em seus trabalhos, os métodos mistos, que representam a melhor técnica para a determinação do índice leptospirósico.
O fato é que tais métodos proporcionam maiores possibilidades de verificação do agente patógeno, justificando plenamente os índices apresentados por esses autores e, a mesma orientação por nós seguida, permitiu apresentar um índice de $78 \%$ em ratos de Curitiba, o que ressalta a importância da combinação dos métodos simples, principalmente, a cultura-inoculação, como foi adotada por GUIDA e MONICI.

Entretanto, acreditamos que o índice encontrado nesta Capital, seja majorado, quando além das técnicas já adotadas, empregarmos as provas sorológicas, que executaremos na continuação destas pesquisas.

Além do valor das técnicas empregadas, o índice de infecção de $78 \%$ é atribuído ao fato de que os ratos observados foram capturados nas margens de rios que atravessam a cidade ou, nas suas imediações, cujas águas possuem elevado teor de dejeções várias, sendo por esta razão, propícias ao desenvolvimento e multiplicação das leptospiras.

$\mathrm{Na}$ Holanda, os inúmeros canais que cortam o País, servem naturalmente de meio de escoamento a dejeções de varias naturezas e foram incriminados por SCHÜFFNER, como sendo fonte de contaminação de muitos casos da Doença de Weil, que surgiram entre os barqueiros e pescadores, por estarem estes em contato direto com as águas.

A biologia do microorganismo etiopatogênico da Doença de Weil, mostra que somente os meios de $\mathrm{pH}$ superior a 7 são os que facultam sua multiplicação e seu poder infectante.

Essa exigência biológica, possivelmente encontrada nas águas desses rios, é devida ao alto teor de matéria orgânica e dejeções facilmente fermentáveis, cujas reações alcalinizam o meio, tornando-o propício ao desenvolvimento das leptospiras. A infecção por esse agente patogênico, processa-se de rato para rato, por intermédio dos alimentos contaminados pela leptospira eliminada pela urina, e quiçá, durante o ato sexual. Sendo a leptospira eliminada pela urina, contamina o solo, a água e os alimentos, conservando-se viva durante 6-7 dias, porém, em condições favoráveis, isto é, na lama do fundo dos canais, nas águas estagnadas, nas margens dos riachos de curso lento, etc., pode viver, saprofiticamente, durante um tempo considerável, originando-se nestas fontes, a infecção humana.

A literatura confirma estes pontos de vista, pois foram descobertas leptospiras de vida livre, avirulentas, que se tornaram patogênicas para o 
homem, uma vez que o meio apresentou condições favoráveis ao seu crescimento e desenvolvimento de poder infectante.

Os ratos submetidos à observação, foram capturados na zona central da cidade, dentro de um pequeno perímetro. A população murídea desta zona, sendo relativamente densa, proporciona facilidades de contaminação pelas diversas vias aos demais componentes da mesma.

O perímetro central da cidade de Curitiba é atravessado por vários pequenos rios, apresentando fatores favoráveis à vida extraparasitária das leptospiras, o que nos parece concorrer juntamente com a densidade murídea, para o elevado índice de incidência encontrada.

Estranho é o fato que, sendo elevado o índice de incidência, não tenha surgido até o presente momento, casos esporádicos e mesmo surto da Doença de Weil.

É provável que certos fatores atuem, favoravelmente ou não, no aparecimento de casos, clinicamente diagnosticáveis. É o que se deduz, examinando-se os índices obtidos por vários autores nacionais em diversas cidades do país, sem que se tenha conhecimento de surtos epidêmicos. Estudando-se as duas epidemias ocorridas no Brasil, uma em Porto Alegre em 1941 e, a outra na Colônia Federal Agrícola "Marquês de Abrantes", Município de Bocaiúva do Sul, em 1946, no Paraná, admitimos que em ambas as ocorrências, houve modificações que romperam o equilíbrio, existente normalmente, entre o individuo e a infecção pelo contato direto do homem com o germe patogênico, devido a grande mortandade de ratos, havida em ambos os casos. Uma das ocorrências foi determinada pela enchente do rio Guaíba, e, a outra, pelas "ratadas", e o intenso extermínio que se seguiu, dos ratos portadores de leptospira.

Em Porto Alegre, supomos que o contato prolongado do indivíduo com as águas estagnadas resultantes da enchente do rio Guaíba, contaminadas pela grande mortandade de ratos, habitualmente, situados nos armazéns do porto e suas proximidades, tenha determinado o surto epidêmico da Doença de Weil.

No caso da epidemia da Colônia Federal Agrícola "Marquês de Abrantes", admitimos que, houve uma exaltação do vírus pelas sucessivas passagens em roedores silvestres, provavelmente, indenes à infecção leptospirósica, em virtude de seu ciclo biológico e "habitat".
Verificados dados concernentes às "ratadas" anteriores ocorridas em outras zonas agrícolas do Paraná e Estados circunvizinhos, não deparamos com nenhuma citação de surtos epidêmicos da Doença de Weil ou de qualquer outra infecção, cujo quadro sintomatológico pudesse admitir certa identidade com a Doença de Weil.

$\mathrm{O}$ surto epidêmico de Leptospirose Icterohemorrágica, ocorrida na Colônia Federal Agrícola "Marquês de Abrantes", caracterizou-se pela rápida progressão e letalidade e teve, parecenos, como provável ponto de partida, a exaltação do vírus pelas sucessivas passagens através dos roedores silvestres, indenes à infecção, cujo contágio efetuou-se pelo contato com os ratos domésticos, reservatórios naturais da leptospira, por ocasião da invasão daquela Colônia pelos ratos famintos que se deslocavam em busca de alimentos nos paióis, roças e campos de culturas.

Esta suposição é feita considerando-se a dificuldade da difusão da leptospira entre os ratos silvestres, pois, conhecendo-se em parte os seus hábitos normais, a pouca índole combativa, a timidez e, nenhuma resistência a outros animais, fugindo sempre ao menor ruído, não formando assim aglomerações, levando vida noturna, alimentando-se, preferentemente, de grãos, raízes e frutas e, habitando zonas pouco povoadas, é o que permite concluir que esses fatores constituem obstáculos biológicos à difusão da leptospira entre esses roedores.

Ao lado desses fatores, outros há que dificultam ainda o crescimento e multiplicação do agente patógeno. A reação ácida do meio ambiente, devido ao alto teor de "húmus" dos solos de "habitat", desses ratos, concorre para facilitar a difusão.

Toda região agrícola está na dependência, também, de outros fatores como: clima, chuvas, ventos, temperatura e umidade, numa estreita correlação dando a cada região, um aspecto peculiar de vida e de condições geográficas, que influem, consideravelmente, na incidência de várias moléstias. Entre os primeiros fatores, podemos incluir o social, o alimentar e o cultura; entre os segundos, salientamos os climáticos, telúricos, topográficos e de vegetação.

Considerando-se estes fatores e a sua ordem de influência, podemos admitir as disparidades na incidência maior ou menor em ratos, cuja biologia estaria afetada. Com relação à maior ou menor sensibilidade dos ratos, às leptospiras, parece-nos nada ter sido até agora verificado. Para isso, será 
necessário um grande número de pesquisas. Tudo isso, parece depender de outros fatores, além dos já citados, como os caracteres individuais, cuja resistência está condicionada aos diversos graus de imunidade por influência de outra natureza. No que diz respeito aos ratos, parece que todas as espécies são suscetíveis de infecção por leptospiras, não parecendo sofrer com o parasitismo, ainda que seu organismo acuse reações. Por esse motivo, acreditamos nas formas frustas da Doença de Weil, somente, diagnosticáveis pelos exames sorológicos.

Embora em menor escala, ao nosso ver, os caninos e suínos podem constituir fonte de contágio da Doença de Weil, motivo este que nos levou a procurar a incidência de leptospira nesses animais. Ao contrário do que se verificou com os murídeos em Curitiba, os cães desta cidade mostraram-se isentos da infecção nas pesquisas efetuadas com a mesma técnica e nas condições usadas para com os ratos. Entretanto, conhecemos casos esporádicos de leptospiras em cães, cujo histórico, quadro clínico e pesquisas laboratoriais, confirmaram sua existência.

Uma particularidade importante que não se verificou foi saber na presente investigação, se os animais examinados tinham caçado ou comido ratos, porque nos casos esporádicos citados acima, constatou-se esta eventualidade.

Estes animais foram fornecidos pela Prefeitura Municipal, que os capturou nas ruas de Curitiba e, eram dados ao hábito de procurarem alimentos nas latas de coleta de lixo, onde facilmente se alimentam.

Acreditamos que o emprego de provas sorológicas precisas na continuação deste trabalho, permitirá apresentarmos em futuro próximo, um índice positivo, mais seguro.

Outrossim, o pequeno número de cães examinados, não permite admitir ou excluir a eventualidade de um índice positivo.

No que se refere aos suínos, o número de exemplares examinados autoriza-nos a afirmar, com mais segurança, ser rara a incidência nesses animais. O número de suínos examinados foi relativamente grande e constou de animais procedentes de várias partes do Estado.

Pretendemos completar os estudos ora iniciados, pois este assunto comporta prolongadas pesquisas pela sua complexidade e os vários aspectos a serem observados.

E de maneira igual ao que se está pesquisando em ratos, pretendemos estender o nosso estudo aos suínos da Colônia Federal Agrícola "Marquês de Abrantes", para vermos o índice de infecção possivelmente positivo em virtude das "ratadas", acompanhadas de surto da Doença de Weil, ocorridas nessa Colônia, em 1946.

\section{CONCLUSÕES}

Os resultados das pesquisas desenvolvidas levamnos a concluir que:

1) $\mathrm{Na}$ zona central da cidade de Curitiba, o índice de leptospira entre os ratos capturados atingiu a 78 por cento, constituindo a maior incidência verificada até o presente momento, no Brasil.

2) O Rattus norwegicus foi a espécie predominante entre os ratos capturados na zona central de Curitiba, na proporção de 49 para 1, isto é, 96 por cento.

3) De acordo com os resultados apresentados, entre os métodos simples, o cultura é preferível ao de inoculação.

4) A combinação desses dois métodos simples, oferece melhores vantagens para a pesquisa da leptospira.

\section{REFERÊNCIAS}

AELLIG (1931), Zeit. Infektinoskr. Haustiere, 39 : 169. ARAUJO, E. (1928), Sc. Med., 6 : 64.

AZEVEDO, A. G. e SANTOS, J. A. (1945), Anais do III Congresso Brás. de Vet. Tese n ${ }^{\circ} 2: 115$.

BACHMANN, A.; QUIROGA, R. e NEGRONI, P. (1944), Microbiologia, Editorial Vazquez. Buenos Aires.

BADUDIERI, B. e CASTAGNOLI, B. (1940), Ann. d'Ig., 50 (4) : 145.

BEAUREPAIRE ARAGÃO, H. (1917), Brasil Médico, $31: 329$.

BUCHMANN, G. (1924), Brit. Med. Journ., 2 : 990.

BUCHMANN, G. (1927), Med. Res. Coun. London Sp. Report, Série $n^{\circ} 113$.

CARINI, A. (1918), Ann. Paul. Med. Cir., 9 : 70.

COSTA, B.; FAILLACE, J. M.; VIEIRA DA CUNHA, C.; SILVA, N. N.; CLAUSELI, D. T.; CHAVES, A. e MEDINA, H. (1942), Arqs. do Departamento Estadual de Saúde Pública Rio Grande do Sul. 3 : 35. DAHR, P. (1937), Klin. Woch., 16 (43) : 1491.

DACORSO FILHO, P. (1940), O Hospital, 18 : 797.

DEANE, M. P. (1946), Com. ao I Congresso InterAmer. de Med. Rio de Janeiro.

ESSEVELD, H.; COLLIER, W. A. e MOCHTAR, A. (1940), Med. Dienst. Volks. Ned. Indie, 29 (1-2) : 1-9. FAIRISE e THIRY (1913), Arch. Parasit., p. 113. FIALHO, A. (1936), Arch. de Hygiene, 6 (2) : 29. 
FIEDLER (1892), Deutsche Arch.f. Klin. Med., 1 : 232. FONSECA, F. e PRADO, A. (1932), Rev. Med. Cir. do Brasil, $40: 65$.

FORATTINI, O. P. (1947), An. Fac. Med. Univ. São Paulo, 23 : 5.

GIOVANNONI, M.; VELLOZO, L. G. C. e KUBIAK, G. V. L. (1946), Arqs. de Biologia e Tecnologia, Curitiba, $1: 185$.

GUIDA, V. O. (1949), Bol. Soc. Med. Veter., 8 (3) : 129.

GUIDA, V. O. e MONICI, N. (1949), Bol. Soc. Med. Veter., 8 (3) : 133.

HIESINGER, F. (1925), Berlin Tierärztl. Wochens., p. 107.

HUEBENER, H. e REITER, H. (1915), Deutsche Med. èlin. Wochens., 41 : 1275.

HUGUENIN, B. e BOURGEOIS, E. (1936), Deuts. Tierärztl. Wochens., p. 485.

INADA, R. e IDO, Y. (1915), Tókio Ijukuski, (198).

IDO, Y.; HOÈL, R.; ITO, H. e WANI, H. H. (1916), Journ. Exp. Med., 24 : 471.

IDO, Y.; ITO, H. e WANI, H. H. (1918), Journ. Exp. Med., $28: 435$.

JOHNSON, D. W. (1943), Brit. Med. Journ., (659).

JUNGHERR, E. (1937), Journ. Amer. Vet. Med. Assoc., $44: 601$.

KLARENBEECK, A. (1928), Tijdschr. Diergeneesk., 55 (5) : 227.

KLARENBEECK, A. e WINSSER, J. (1937), Deuts. Tierärztl. Wochens.

KORTHOF, G. (1930), Nederl. Tijdschr. Geneesk., 74 (33) : 4097.

KOUWENAAR, W. e WOLFF, J. M. (1930), Nederl. Tijdschr. Geneesk., 74 (4) : 376.

KRIVACEK, O. (1924), Zeit. Hyg. Infeltionskr., 103 (3) : 529.

KRUMBEIN, R. e FRIELING, B. (1916), Deutsche Med. Wochens., 42 : 564.

LARREY, D. J. (1812), Memories de Chirurgie Militaire em Campagne, Paris, Editeur Smith.

LARSON, C. L. (1914), Public. Health Reports, 56.

LINS, A. (1928), Ciência Médica, 6 (1) : 164.

LUCREZI, G. (1940), Boll. Inst. Sierotrap. Milanese, 19 (5) : 244.

LUCET, A. (1910), Recueil Méd. Veter., 1 : 87.

LUKES e DERBECK, M. (1923), Arch. Tierärztl., p. 25.

LUKES, J. (1924), Ann. Inst. Pasteur, 38 (6) : 523.

MAC DOWELL, A. L. (1925), Bol. Acad. Med. Rio de Janeiro, p. 420.

MADUREIRA PARÁ (1946), Arch. Pathology, 42 (6) : 649.

MARTIN, L. e PETTIT, A. (1919), Spirochétose Icterohemorrhagique, Masson et Cia. Editeurs.

MELANIDI, C.; TZORTZAKI, N. e DEBONERA, G. (1933), Rev. Gener. Med. Vet.
MEYER, È. F.; ANDERSON STEWART, B. e EDDI, B. (1929), Amer. Journ. Pub. Health, 29 (4) : 347.

MIYAJIMA, M. (1915), Bol. Soc. Med. Cir. S. Paulo, 2 $: 5$.

MOCHTAR, A. (1940), Geneesk. Tijdschr. Nederl., Indie, 80 (40) : 2334.

MONLUX, W. S. (1948), The Cornell Veter., 38 (1) : 57.

MONLUX, W. S. (1948), The Cornell Veter., 38 (2) : 109.

MONLUX, W. S. (1948), The Cornell Veter., 38 (3) : 199.

NOGUCHI, H. (1917), Journ. Exp. Med., 25 : 755.

NOGUCHI, H. (1918), Journ. Exp. Med., 27 : 593.

NOGUCHI, H. (1919), Journ. Exp. Med., 30 : 95.

NORONHA DE MIRANDA, R. (1946), Rev. Med. do Paraná, 15 (6) : 229.

NIESCHULZ, O. e WAWO-ROENTOE, F. È. (1930), Tidjs. V. Diergeneesk, p. 282.

OKELL, C. C.; DALliNG, T. e PUGH, L. P. (1925), Vet. Jorn., $81: 3$.

OKELL, C. C.; DALliNG, T. e PUGH, L. P. (1925), Brit. Med. Jour., 1 : 34.

OTTOSEN, H. E. (1939), Maanedsskr. Dyrl., 51 : 15.

PANISSET, L. e VERGES, J. (1925), C. R. Acad. Sc., (1) : 1296 .

PETTIT, A. (1928), La Biologie Medicale, (2-4).

PETERSEN, C. B. e JACOBSEN, E. (1937), C. R. Soc. Biol., 126 (31) : 797.

PETERSEN, C. B. e JACOBSEN, E. (1937), C. R. Soc. Biol., 124 (31) : 799.

PEREIRA, C. (1941), Arqs. Biol. S. Paulo, 12 : 175.

PROKOPANOFF, A. (1939), Tierärztl. Rdsch., p. 464.

RAVEN, C. (191-), Jour. Infect. Dis., 20 (2) : 131.

REITANO, V. e MORSELLI, G. (1935), Giorn. Batt. Imm., 15 : 454.

REITER, H. (1935), Bull. Offic. Intern. Hyg. Publ., 29 : 2343.

CABLAYROLlES, A. (1928), These. Ecole de Toulouse.

SANDEK, H. (1935), Arch. für Hyg. und Bakt., p. 270.

SARDJITO, M.; MOCHTAR, A. e WIRASMO, R. M. (1937), Geneesk. Tijdschr. Nederl., Indie, 77 : 457.

SAVINO, E. e RENNELLA, E. (1944), Leptospira y Leptospirosis en la Republica Argentina. Talleres Graficos. Tomas Palumbo.

SAVINO, E. e RENNELLA, E. (1945), Rev. Assoc. Med. Argentina, 59 : 262.

SCHÜFFNER, W. (1934), Trans. Roy. Soc. Trop. Med. Myg., 28 (1) : 7.

SCHÜFFNER, W. e WALCH-SORGDRAGER, B. (1937), Bull. Off. Interm. Publ. (Sociète des Nations). p. 292.

SCHÜFFNER, W. e WALCH-SORGDRAGER, B. (1938), Zentralb. f.Bakt. Orig. 141 (3-4) : 97.

SEFTON, B. (1938), Bras. Méd., 52 (16) : 379.

SMILLIE, W. G. (1921), An. Paul. Med. Cir., 12 : 182. 
SNAPPER, J.; CHUNG, H. L.; CHU, J. e CHEN, K. (1940), Chinesse Med. Journ., 58 (4) : 408.

UHLENHUTH, P. e FROMME, W. (1915), Medizinische Klinik, (44) : 1202.

UHLENHUTH, P. e FROMME, W. (1918), Deutsche Med. Wochens., 44 : 705.

UHLENHUTH, P. e ZIMMERMANN, E. (1936), Zblat. Bakt. Orig., 135 : 391.

VAN DER WALLE, N. (1938), C. R. Soc. Biol., 128 (31) : 804.

WALCH-SORGDRAGER, B. (1939), Bull. Orgnis. Hyg., (Sociète des Nations).

WOLBACH, S. B. e BINGER, C. A. L. (1914), Journ. Med. Res., 30 : 23.

WEIL, A. (1886), Deuts. Archs. für Klinische Med., 39 : 209 .

ZUELZER, M. (1921), Vortag e der Gesesls. Naturforsch. Fremade Zu Berlim. 


\section{FIGURAS}

1 a 11 


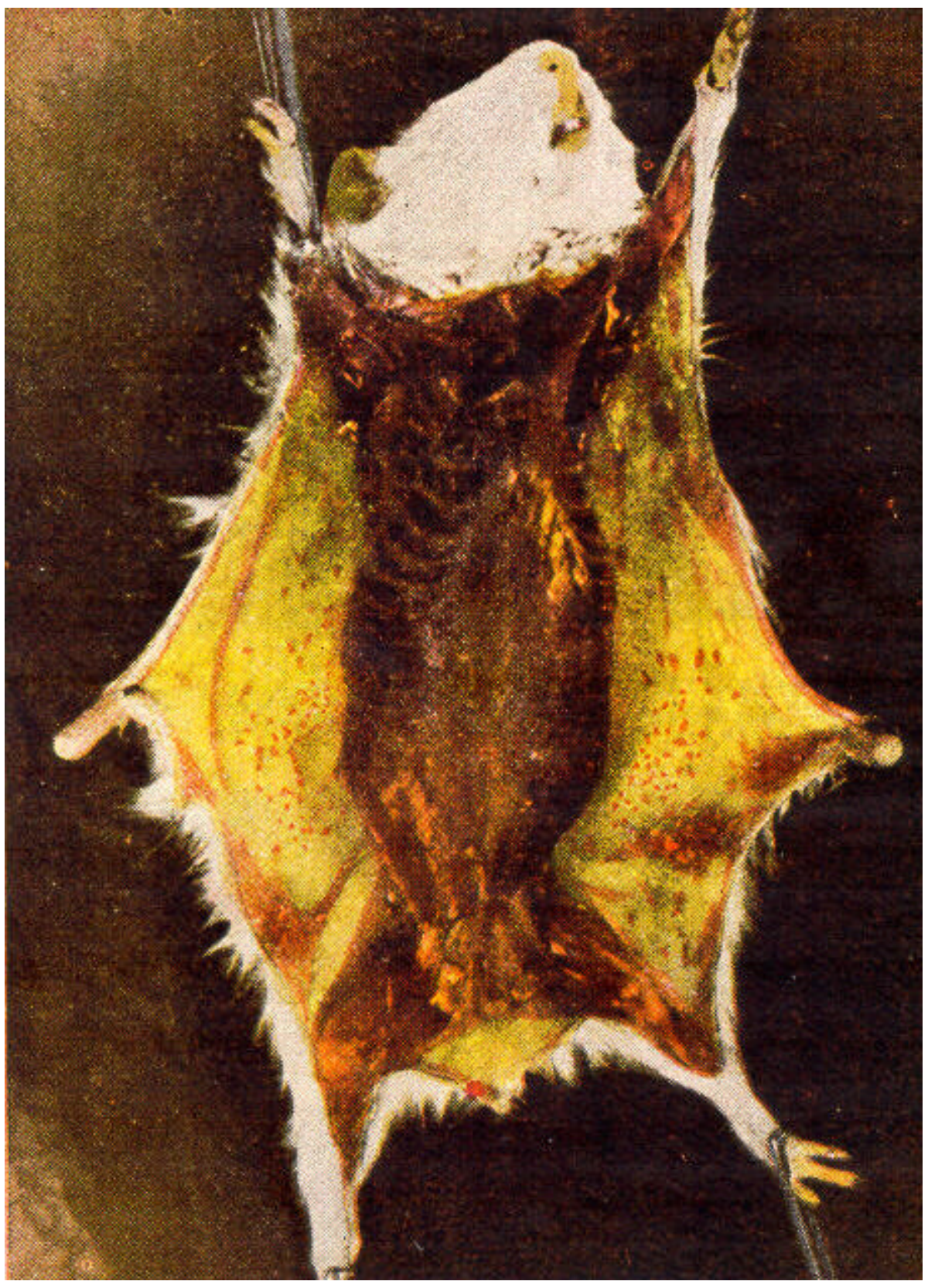

Fig 1 - Cobáio inoculado com Leptospira icterohaemorrhagiae isolada de rato, apresentando icterícia e hemorragias. Original. Fot. Medina. 


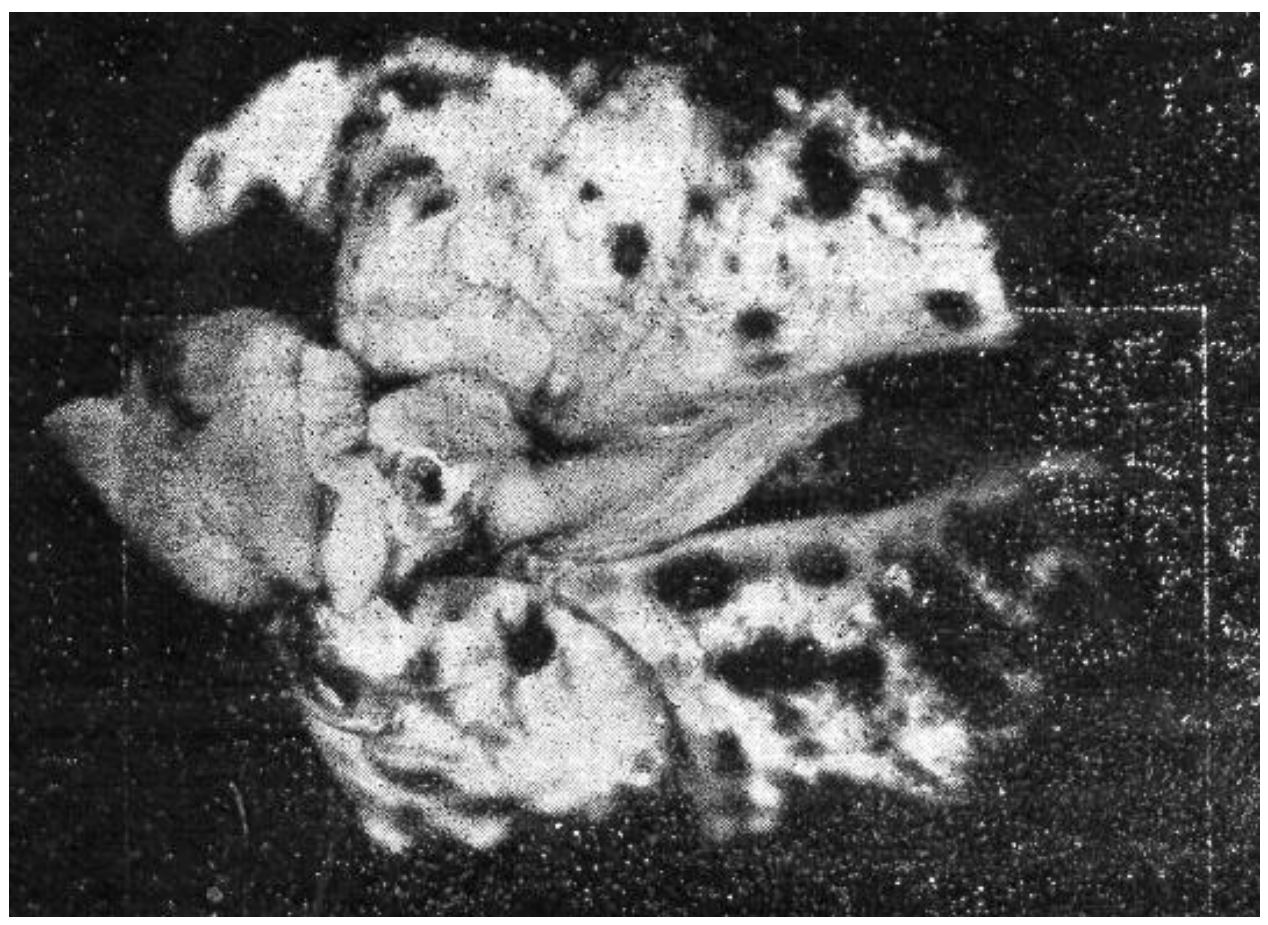

Fig. 2 - Pulmões de cobáio mostrando hemorragias, alterações que lhes emprestam o aspecto de "pulmão em asa de borboleta". Original. Fot. Medina.

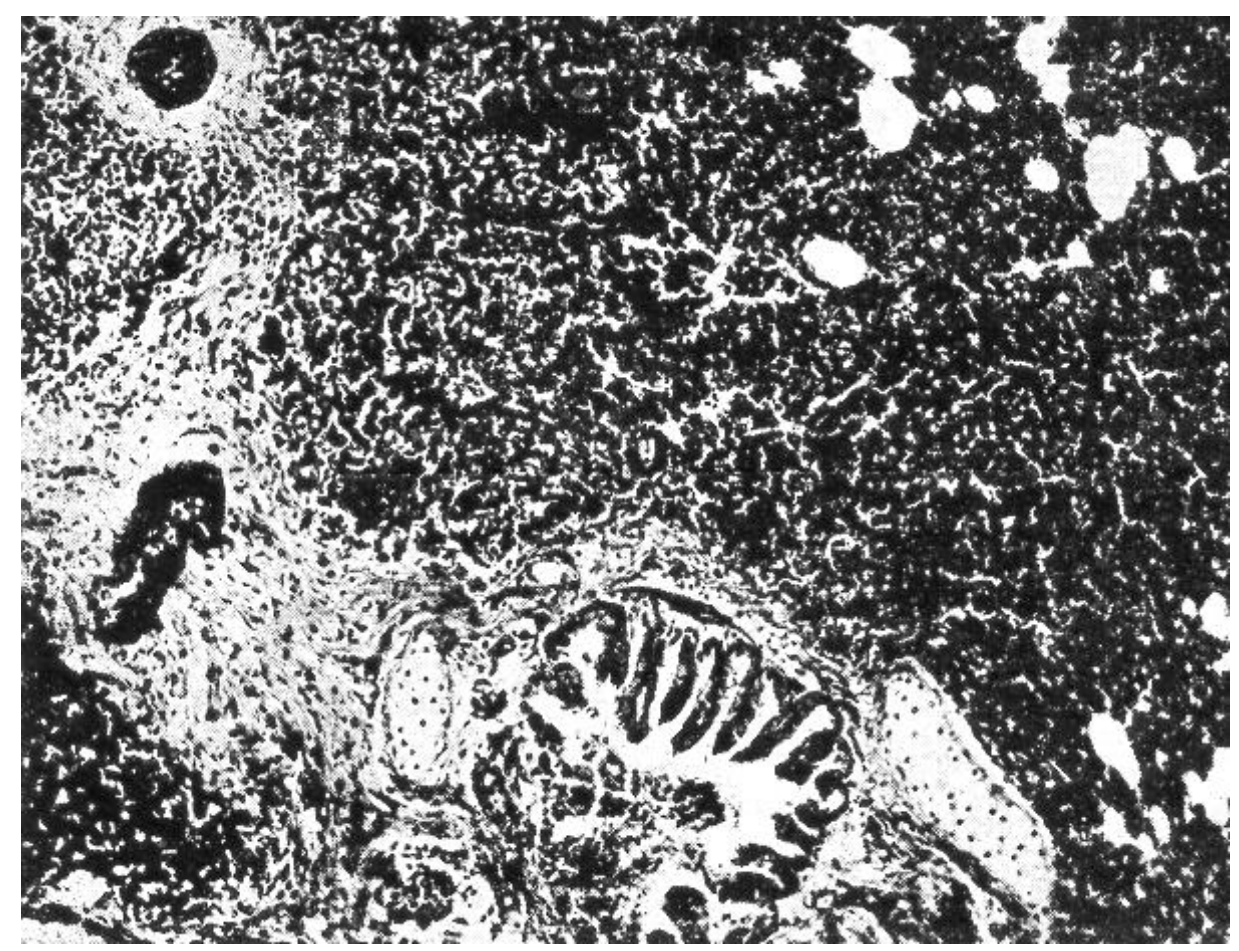

Fig. 3 - Corte de pulmão de cobáio com hemorragia intra-alveolar. Col. Hematoxilinaeosina. Original. Fot. Medina. 


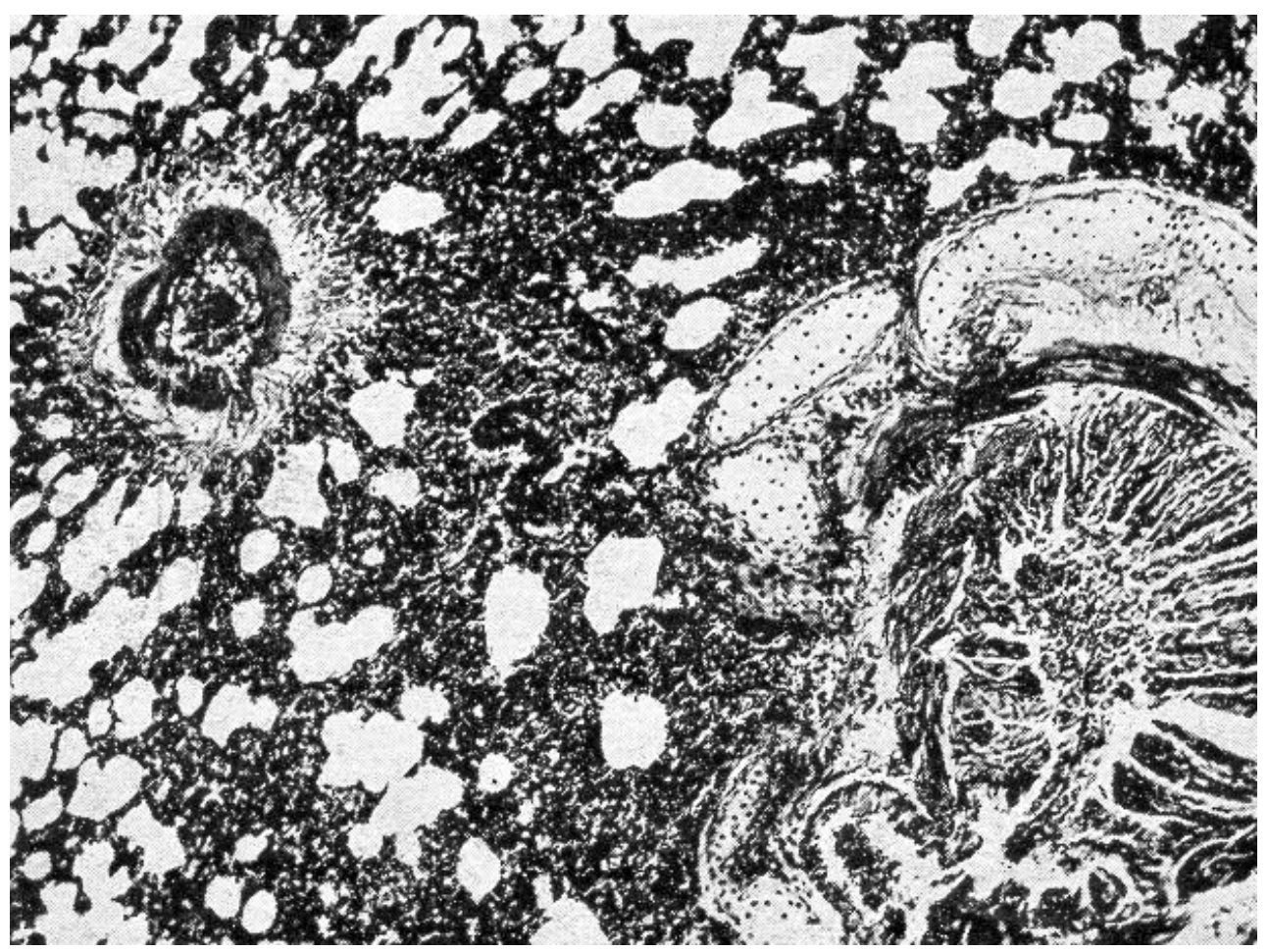

Fig. 4 - Corte de pulmão de cobáio com hemorragia intra-alveolar. Col. Hematoxilinaeosina. Original. Fot. Medina.

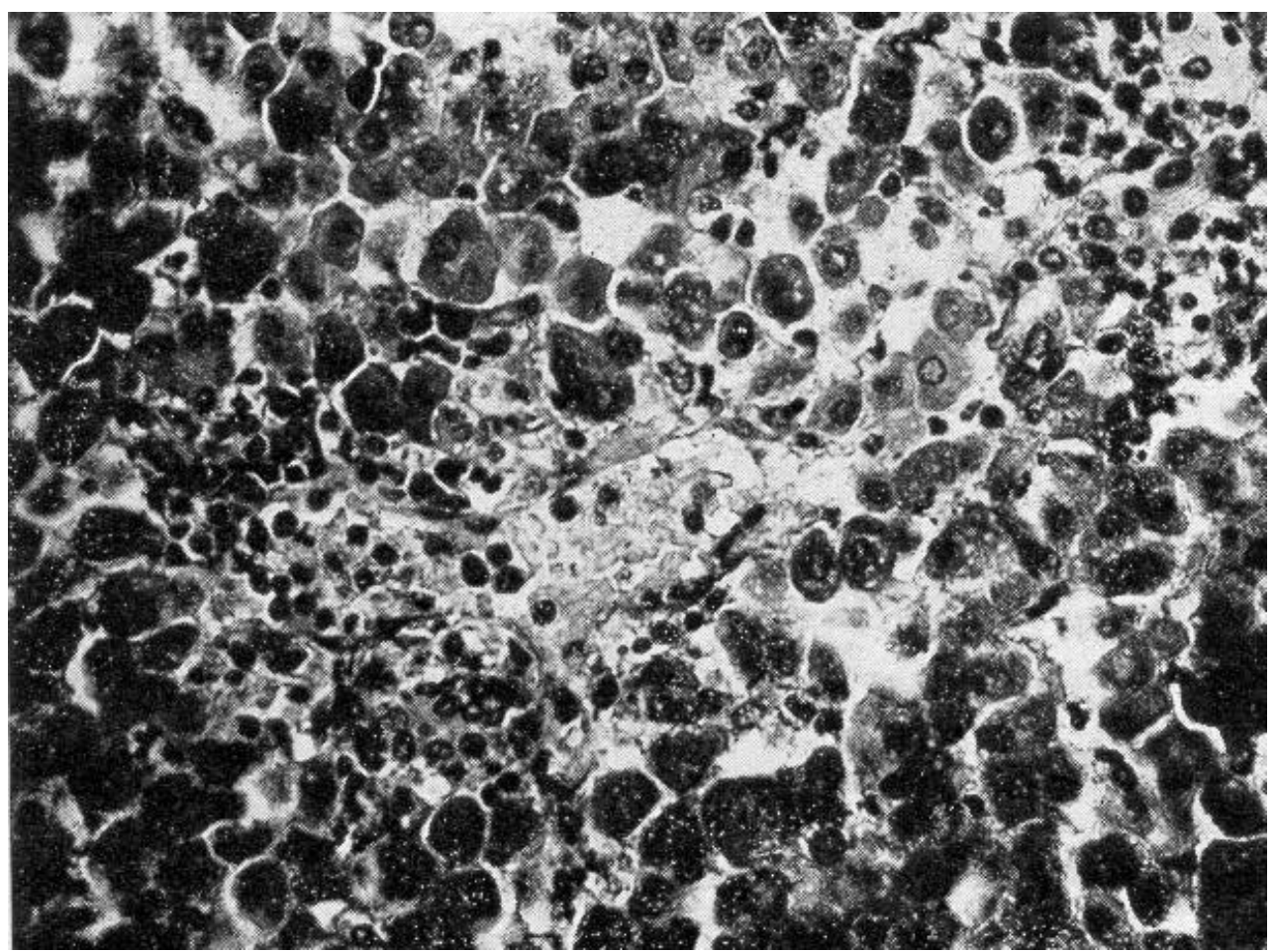

Fig. 5 - Corte de fígado. Observa-se dissociação trabecular, perdendo as traves de Remak a disposição radiada que possuem, em volta da veia centro-lobular. Col. Hematoxilina-eosina. Original. Fot. Medina. 


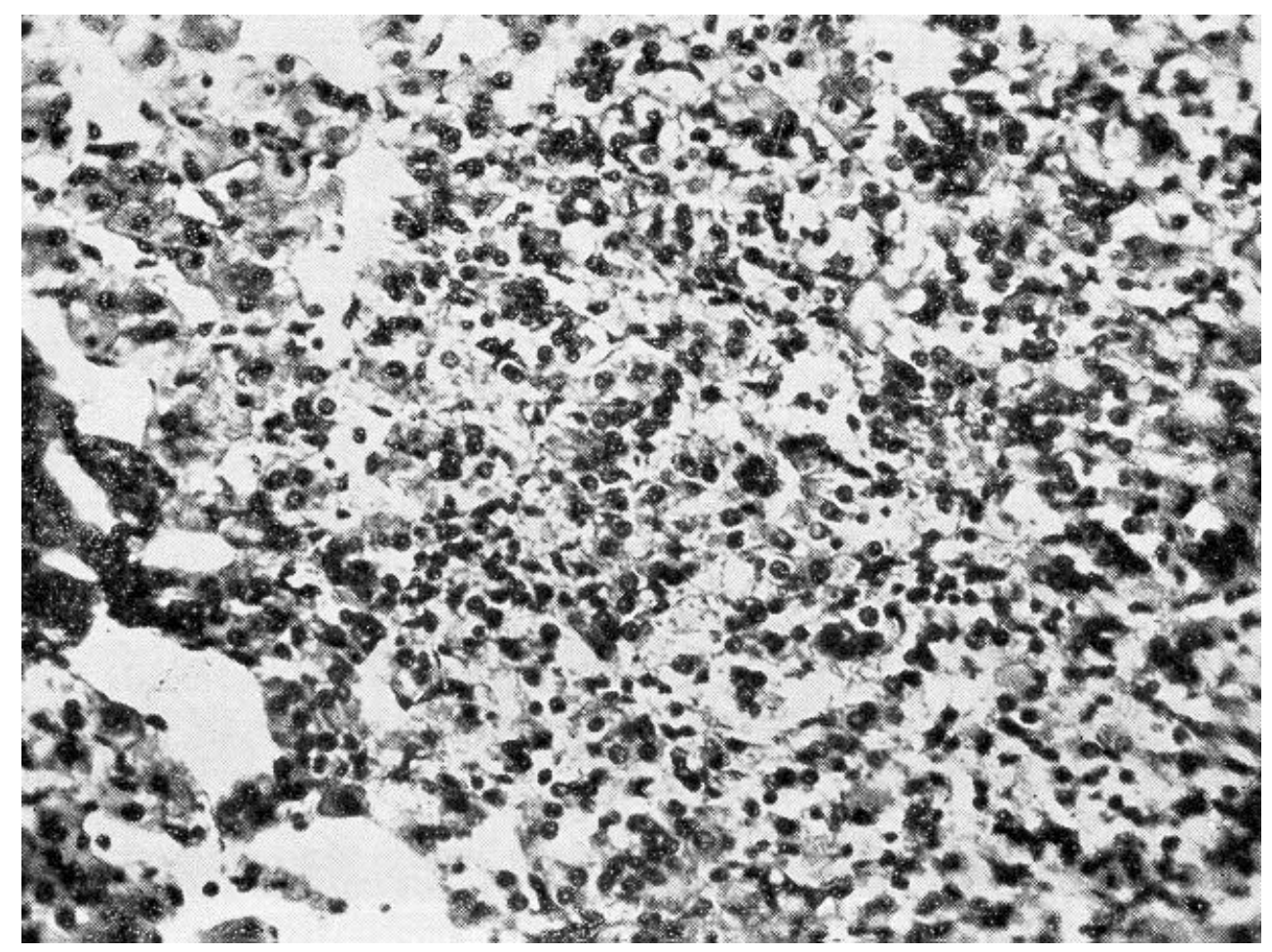

Fig. 6 - Camada reticular da suprarrenal, hemorrágica e infiltrada por elementos inflamatórios. Col. Hematoxilina-eosina. Original. Fot. Medina.

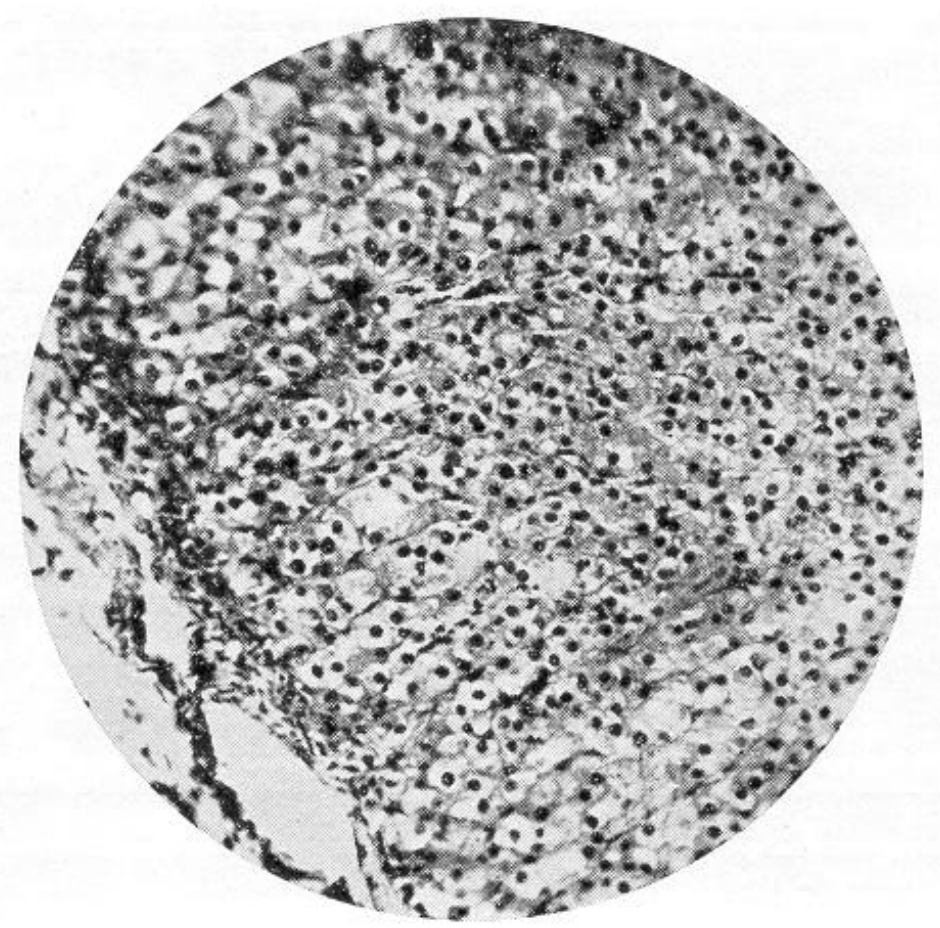

Fig. 7 - Elementos celulares da cortical mostrando numerosos vacúolos. Col. Hematoxilina-eosina. Original. Fot. Medina. 


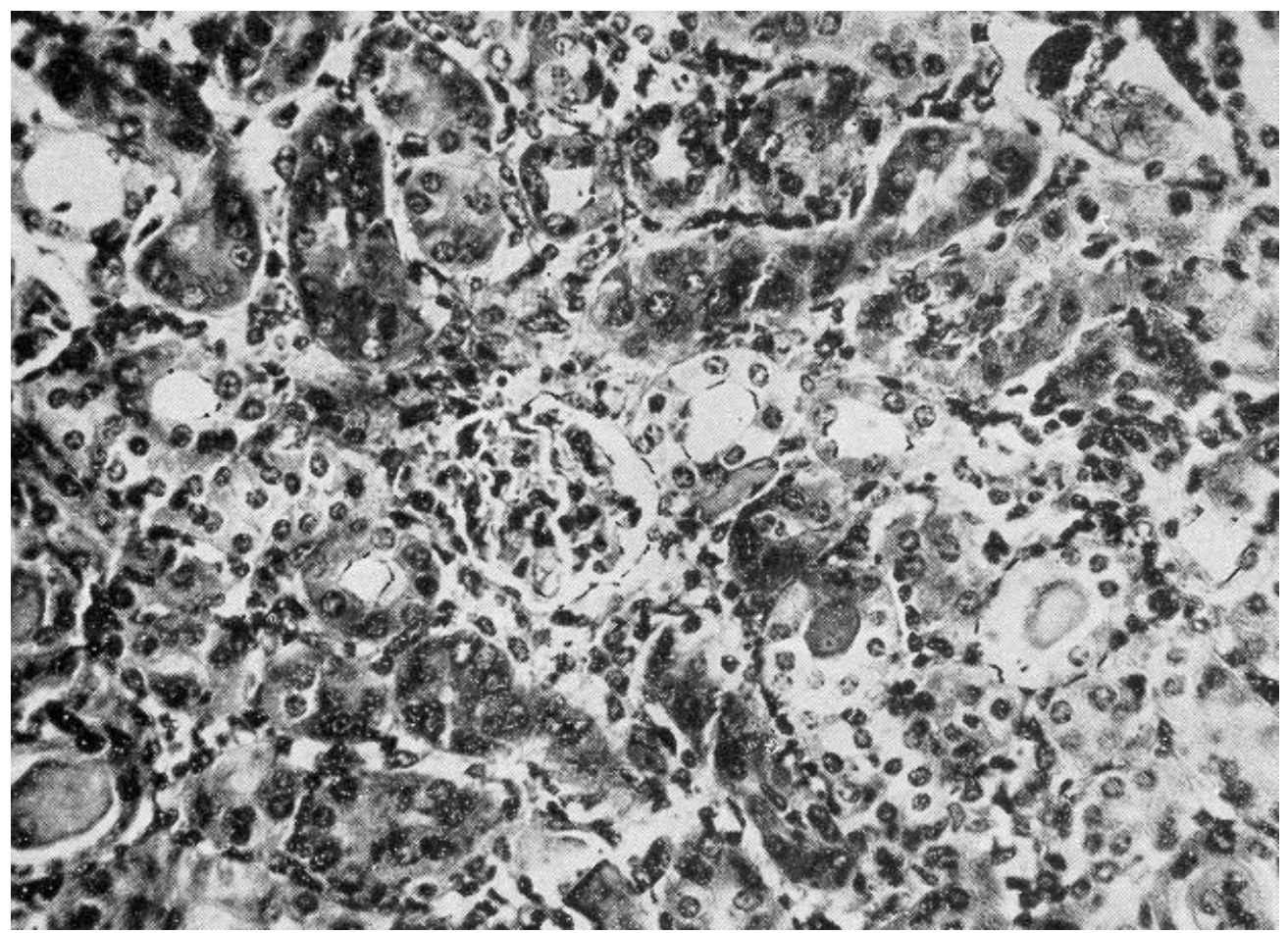

Fig. 8 - Nefrite leptospirósica, onde se observam modificações degenerativas, hemorragias, etc. Col. Hematoxilina-eosina. Original. Fot. Medina.

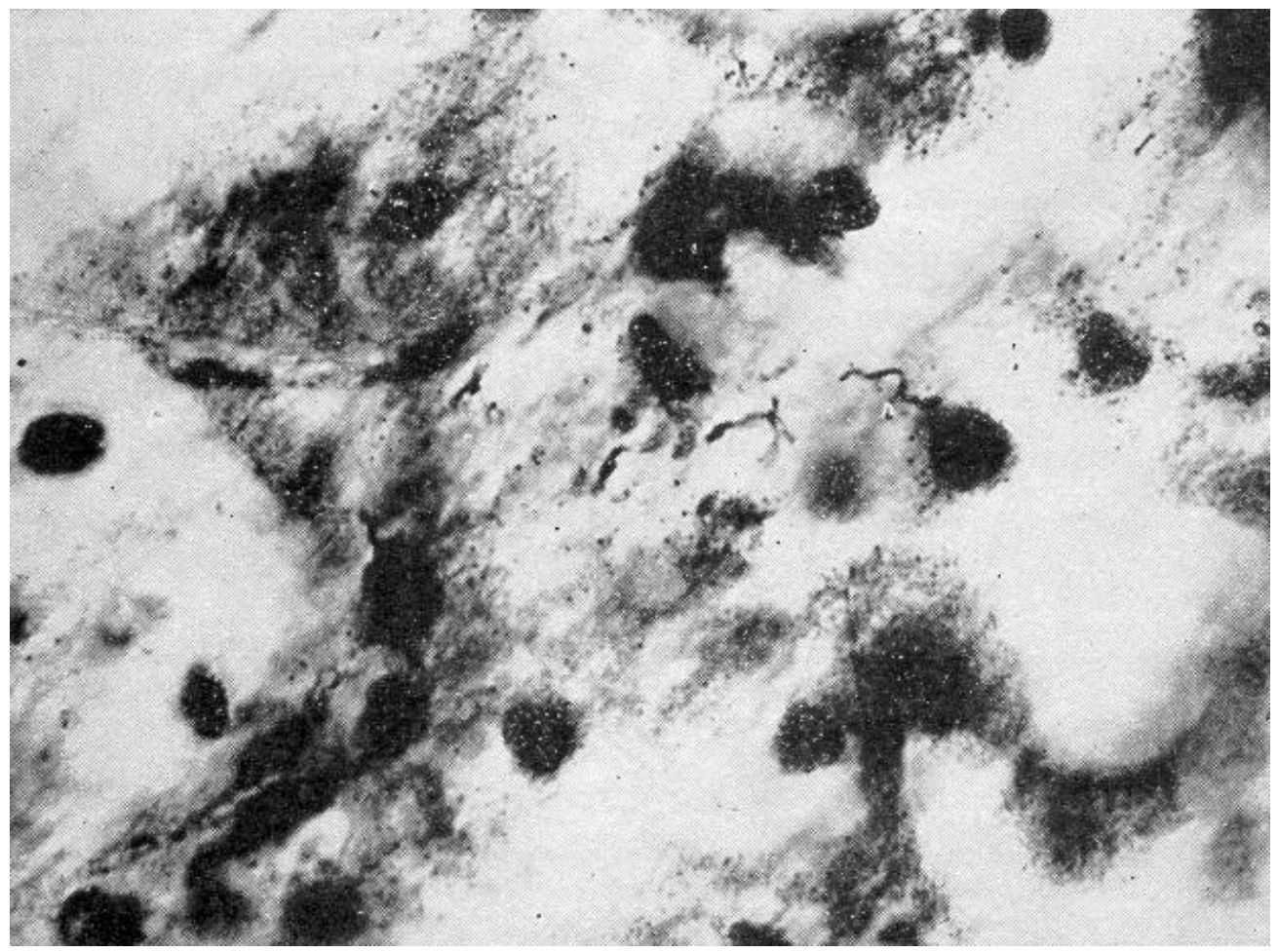

Fig. 9 - Corte de rim impregnado pela prata, mostrando leptospiras. Impregnação argêntica (Método Medina). Original. Fot. Medina. 


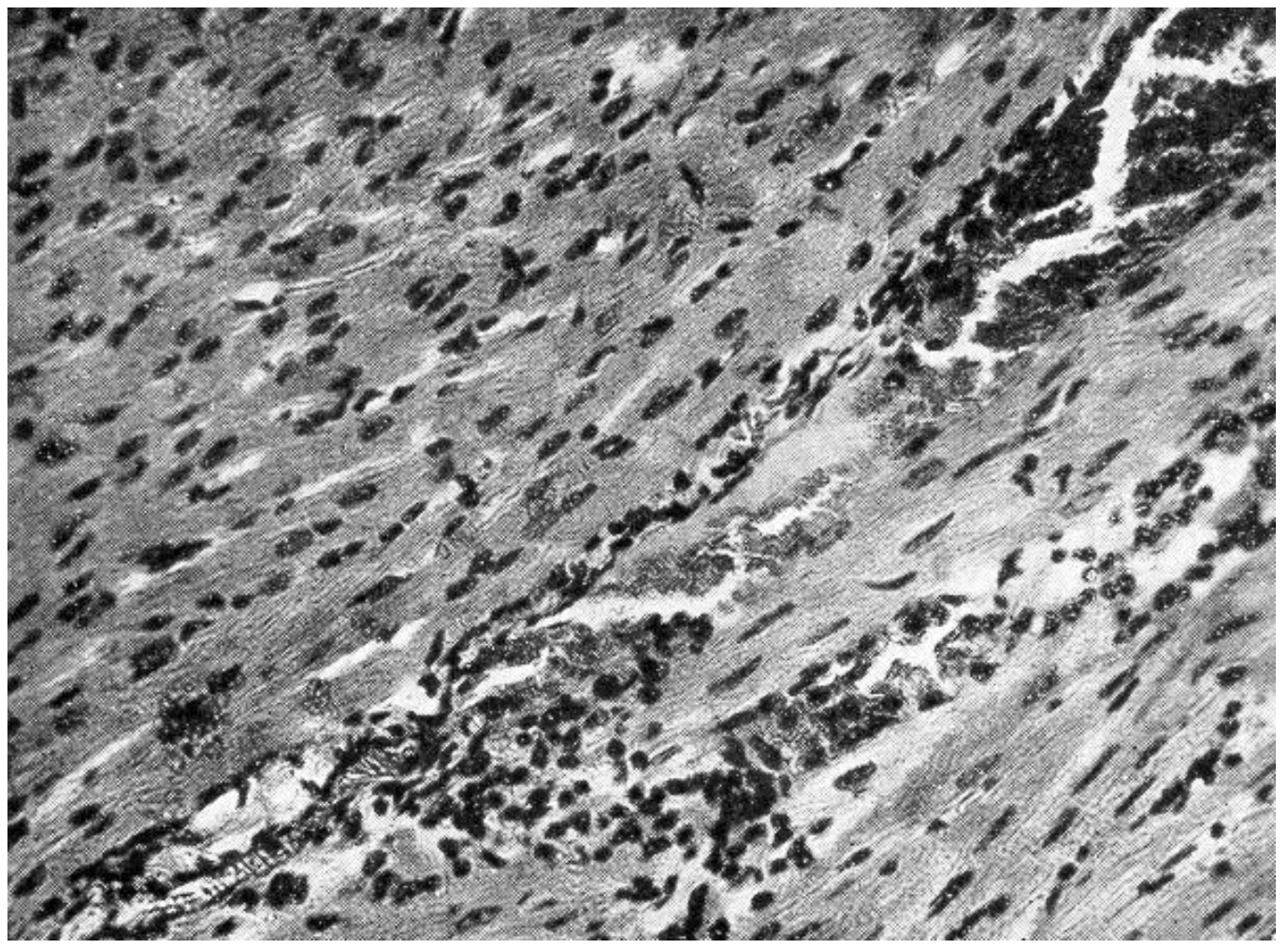

Fig. 10 - Corte do músculo cardíaco apresentando foco hemorrágico e inflamação intersticial. Col. Hematoxilina-eosina. Original. Fot. Medina.

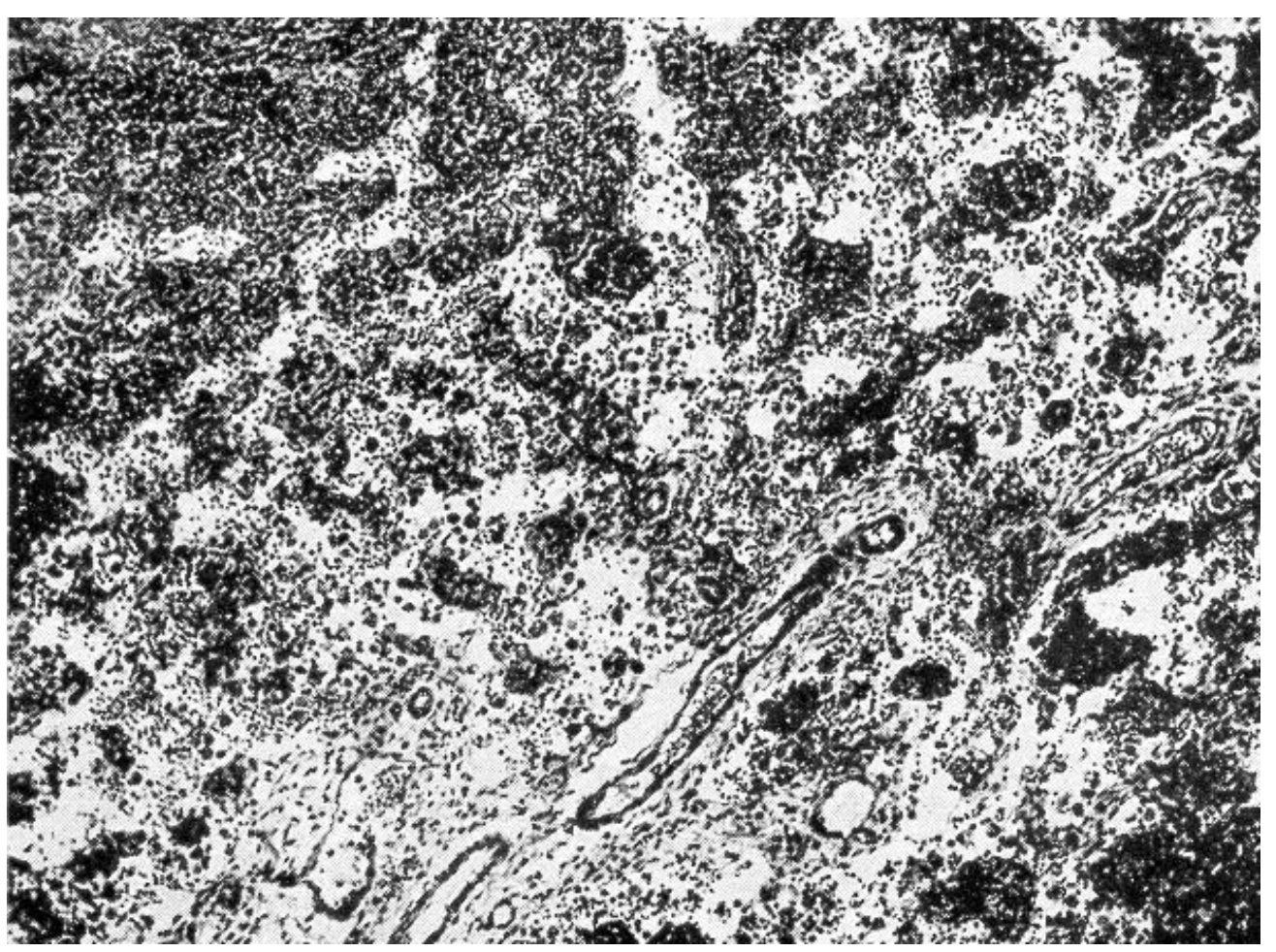

Fig. 11 - Corte de gânglio linfático mostrando intensa mobilização celular e extravasamento sanguíneo. Col. Hematoxilina-eosina. Original. Fot. Medina. 